\title{
LA GÉNESIS DOCUMENTAL EN LA CANCILLERÍA REAL DE ALFONSO $X$
}

\section{THE GENESIS OF THE DOCUMENTS DURING THE CHANCELLERY OF ALFONSO $X$}

\author{
Antonio J. LÓPEZ GUTIÉRREZ \\ Universidad Pablo de Olavide
}

Resumen: La cancillería real de Alfonso X representa uno de los hitos más relevantes para el estudio de la configuración de la futura Administración española. Uno de los temas menos conocido de su reinado es el proceso seguido para la elaboración de sus documentos - génesis documental- Desaparecidos los registros de la cancillería castellana la utilización de las fuentes legales alfonsíes: Espéculo, Fuero Real y Partidas y los documentos del monarca han sido fundamentales para la confección de este trabajo. Abordamos las diferentes fases por las que atraviesa su elaboración tanto en la "actio" como en la "conscriptio" que hemos dividido en documental y cancilleresca. Esta división obedece por una parte, a los diferentes lugares donde se elaboraron los documentos; y por otra, al reforzamiento de la idea que en la época se tenía de la cancillería como lugar donde se validaban y cancelaban los documentos.

Palabras clave: Alfonso X, génesis documental, cancillería castellana, diplomática real castellana.

Abstract: The Chancellery of Alfonso X represents one of the most significant milestones for the study of the configuration of the future Spanish Administration. One of the least known subjects of his reign is the process followed to draft his documents - the genesis of the documents-. Having disappeared the records of the Castilian Chancellery, the use of the legal sources of Alfonso X like: Speculum, Fuero Real, Partidas and the Monarch's documents have become essential to develop this work. This work approaches the different stages of construction of the document, from its "actio" to its "conscriptio" which we have divided into "documental" and "cancilleresca", respectively. This division is due to, on one hand, to the different places in which documents were created and on the other hand, to the strengthening of the belief that the Chancellery was the place where the documents were validated and cancelled.

Keywords: Alfonso X, the genesis of the documents, Castilian Chancellery, Royal Castilian Diplomatics. 
El estudio diplomático de la cancillería real de Alfonso X comporta el abordar varias cuestiones: génesis, tradición y formas documentales que conforman los pilares básicos sobre los que se asienta el funcionamiento de la cancillería alfonsí. Estas tres cuestiones fueron abordadas, con motivo de la realización de mi Tesis Doctoral ${ }^{1}$. Desde entonces he publicado una serie de artículos dedicados unos a la tradición documental ${ }^{2}$, a la sigilografia ${ }^{3}, \mathrm{y}$ otros a la existencia de los registros de cancillería en tiempos de Alfonso $X^{4}$. Qué duda cabe que el tema de los registros de la cancillería castellana incide de forma directa en el estudio de la génesis documental por cuanto se presenta como uno de los momentos claves de la conscriptio documental.

Por ello, en el tema de la génesis documental toma especial relevancia el hecho de no contar con los registros de cancillería para el periodo que estudia$\operatorname{mos}^{5}$, en el sentido de que no podemos cotejar con estas fuentes la realidad docu-

${ }^{1}$ Cuando una obra se cita más de una vez, en la primera referencia se indica el título abreviado entre [ ]. Vid. A. J. LÓPEZ GUTIÉRREZ, La cancillería de Alfonso X a través de las fuentes legales y la realidad documental, Oviedo, 1990 (Microficha) [La cancillería de Alfonso X].

${ }^{2}$ Vid. A. J. LÓPEZ GUTIÉRREZ, "La tradición documental en la cancillería de Alfonso X", Historia, Instituciones y Documentos, 19 (1993), pp. 253-266.

${ }^{3}$ Vid. A. J. LÓPEZ GUTIÉRREZ, "Sevilla, Alfonso X y el sigillum aureum”, Archivo Hispalense, 220 (1989), pp. 309-320; "La sigilografía en las fuentes legales alfonsíes", en Actas del Primer Coloquio de Sigilografia, Madrid, 1990, pp. 125-135.

${ }^{4}$ Vid. A. J. LÓPEZ GUTIÉRREZ, "Registros y registradores en la cancillería de Alfonso X", en Estudis Catellonencs. Miscellania d'estudis dedicats a la memoria del profesor Joseph Trenchs I Odena, Valencia, 1995, pp. 721-736; Vid. Ma. J. SANZ FUENTES y A. J. LÓPEZ GUTIÉRREZ, "Registros y registración en la cancillería real castellana durante la Edad Media", Der Einfluss der Päpstlichen Kanzlei auf das Europäische Urkundenwsen. Hoch-und-Spätmittelalter, Heilderberg, 1996 (inédito). A. J. LÓPEZ GUTIÉRREZ, “Oficio y funciones de los escribanos en la cancillería de Alfonso X”, Historia, Instituciones y Documentos, 31 (2004), pp. 353-368; “Los registros de la cancillería castellana durante la baja Edad Media”, en La escritura de la memoria. Los registros, VIII Jornadas de Ciencias y Técnicas Historiográficas, Barcelona, 2010, pp. 39-72.

${ }^{5}$ Las noticias sobre la pérdida de los registros de la cancillería castellana nos la proporciona Pedro Mártir de Anglería, indicándonos que fueron pasto de las llamas a consecuencia de la Guerra de los Comuneros. En este sentido debemos destacar el trabajo de F. ARRIBAS ARRANZ, "Los registros de cancillería de Castilla", Boletín de la Real Academia de la Historia, t. CLXII, Cuaderno II (1968), pp. 171-200 y t. CLXIII, cuaderno I, pp. 143-162; Ma S. MARTÍN POSTIGO, Historia del Archivo de la Real Chancillería de Valladolid, Valladolid, 1979; M ${ }^{\mathrm{a}}$ A. VARONA GARCÍA, La Chancillería de Valladolid en el reinado de los Reyes Católicos, Valladolid, 1981; L. PASCUAL MARTÍNEZ, "Apuntes para un estudio de la cancillería del rey Fernando IV de Castilla", en Estudis castellonencs, Miscellania d'estudis dedicats a la memoria del profesor Joseph Trenchs I Odena, Castellón, (1994-1995), pp. 1021-1036, en cuyo desarrollo rebasa el estudio de la figura del registrador hasta 1447. Vid. A. de la PLAZA BORES, Archivo General de Simancas. Guía del Investigador, Madrid, 1986, p. 24; Revista de Archivos, Bibliotecas y Museos, t. LXV, p. 273; J. L. RODRÍGUEZ DE DIEGO, Instrucción para el gobierno del Archivo General de Simancas, Madrid, 1998; V. MONTOJO MONTOJO, "Los fondos archivísticos como fuentes para el estudio de las cancillerías reales en las edades media y moderna”, Miscelánea Medieval Murciana, 23-24 (2003), pp. 257-170. 


\section{ANTONIO J. LÓPEZ GUTIÉRREZ \\ LA GÉNESIS DOCUMENTAL EN LA CANCILLERÍA REAL DE ALFONSO X}

mental relativa a la actio y conscriptio. Esta comprobación sólo podrá efectuarse en determinados documentos en los que quedaron reflejados los momentos procesales que tanto la actio como la conscriptio comportan: petitio, intercesio, consensun, registratio ${ }^{6}$, mientras que en otros como la emendatio, por citar algunos de ellos, seguiremos las noticias que sobre el tema nos suministran tanto el Espéculo, como Las Partidas?.

Todas estas noticias nos ayudarán a reconstruir el funcionamiento de la cancillería castellana en tiempos de Alfonso X. Funcionamiento que, como podrá comprobarse, calificamos de "cautelar" por la continua atención que se le presta en los distintos momentos de la elaboración del documento y que debemos entenderlo en un doble sentido. En primer lugar, por la rigidez con la que este sistema afronta todos los momentos de la actio y conscriptio documental, fruto de la naturaleza jurídica de las fuentes que entendemos recogen una praxis cancilleresca que se llevaba a cabo en cancillería. En segundo lugar, por la dificultad de fijar con exactitud la fecha de redacción tanto del Espéculo como Las Partidas, o si se prefiere con más exactitud: si todas las partes de ambas obras legislativas fueron confeccionadas de manera sincrónica o diacrónica, toda vez que aceptamos el hecho de que dichas fuentes recogen una práctica ya usual en la cancillería castellana ${ }^{8}$.

Por tanto, el estudio de la génesis documental no debe entenderse de modo aislado sino como el proceso que va del no ser al ser del documento y constituye uno de los apartados más interesantes a la hora de realizar el estudio del funcionamiento de una cancillería, por cuanto en su cauce se derrama la actividad política y administrativa del monarca hasta llegar a conformar y formar el documento totalmente confeccionado, para subvenir a las necesidades político-administrativas del reino.

Dentro de la génesis documental distinguimos las dos fases principales: $a c$ tio y conscriptio que comportan del no ser al ser del documento.

${ }^{6}$ A lo largo del artículo efectuaremos numerosas alusiones a estos momentos. Vid, por ejemplo P.3-18-14; P.3-18-24; y el conjunto de documentos citados en el desarrollo del presente trabajo.

${ }^{7}$ Sobre la emendatio, Vid. P. 3-20-4.

${ }^{8}$ Cada vez resulta más necesario la formación de un equipo interdisciplinar compuesto por historiadores, diplomatistas, juristas, archiveros e historiadores del arte que compartan de manera simultánea sus conocimientos para esclarecer muchas dudas que hoy se mantienen con respecto a la redacción de las fuentes legales alfonsíes. 


\section{ACTIO}

En la actio distinguiremos una serie de fases:

\subsection{Petitio}

Es el punto de partida para la concesión de muchos documentos, aunque no se trata de un requisito indispensable para ello, porque como señaló A. Pratesi, en el proceso de elaboración de un documento cabe distinguir los que emanan de la actividad política y administrativa del autor por su directa voluntad; de aquellos otros que son solicitados por sus súbditos. En ambos casos nos encontramos ante lo que el propio autor denomina "génesis del documento público" porque, ni que decir tiene, la cancillería expide documentos públicos ${ }^{9}$.

Precisamente la segunda distinción apuntada — solicitud - es la que dará lugar a la posible, pero no necesaria, primera fase de la actio documental: la petitio.

Las fuentes y los documentos nos ofrecen innumerables ejemplos de esta fase previa a la redacción del documento. A ellos nos referiremos a continuación:

De auenencias que fazen muchas vegadas ricos omes o caballeros e otros omes entre sí... si ellos vinieren auenidos, e pidieron merced al rey ${ }^{10}$.

Merced piden al rey algunos de los que an ganado que les dé sus cartas, porque anden más seguros ${ }^{11}$.

Peticiones fazen los omes con cartas del apostólico... e demandan al rey cartas ${ }^{12}$.

Si contra derecho comunal de algún pueblo, o a daño dél fueren dadas algunas cartas... la non ha fuerça...; más déuelo mostrar al rey, rogándole e pidiéndole merced $^{13}$.

Otrosí dezimos que si alguno ganare carta del rey de perdón de malfetrías que aya fecho... diciendo alguna partida de aquello, porque le pide perdón o porque le ruega e encubriéndo lo $\mathrm{al}^{14}$.

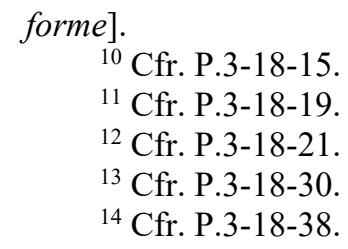
forme].

${ }^{10}$ Cfr. P.3-18-15.

${ }^{11}$ Cfr. P.3-18-19.

${ }^{12}$ Cfr. P.3-18-21.

${ }^{13}$ Cfr. P.3-18-30.

${ }^{14}$ Cfr. P.3-18-38.

${ }^{9}$ Vid. A. PRATESI, Genesi e forme del documento medievale. Roma, 1979, p. 36 [Genesi e 
Van afincadamente e demandan omes y ha, a las vegadas a los reyes, que les den priuilegio e cartas ${ }^{15}$.

Igualmente, los documentos emanados de la cancillería alfonsí recogen en su tenor documental la alusión a la petitio:

E pidióme por merced que yo que les declarasse de mío oficio, por sentencia, estos térmenos por estos logares sobredichos por suyos de la horden, e que auía derecho de uos defender que les non entrássedes en estos térmenos sin so placer a so danno ${ }^{16}$.

Pidiéronme merçed que yo que les mandasse dar mis cartas abiertas que traxiessen por la tierra en logar del priuilegio ${ }^{17}$.

Et porque la carta era fecha en papel e auía tiempo que la nos auiemos dada, don Remondo, arçobispo de Seuilla, rogónos e pidiónos merçed que la mandásemos dar en cuero ${ }^{18}$.

Como podrá comprobarse en los ejemplos mencionados, tres son los verbos que se utilizan para este acto: pedir, demandar y rogar. No hemos podido puntualizar si para determinados asuntos, se usaba concretamente uno de estos tres verbos. Nuestra opinión es que unos y otros eran irrelevantes y que los tres aluden precisamente a lo que la petitio comporta. Las matizaciones que el Diccionario de Autoridades efectúa en el significado de estos tres verbos entendemos que no son determinantes en su uso. Lo que sí está claro, y antes nos hemos referido a ello, es que los tres verbos, indicativos de la existencia de la petitio, se plasman en los documentos.

De los ejemplos citados hemos elegido a dos: aquellos que se corresponden con las notas $\mathrm{n}^{\mathrm{o}} 11$ y 13 , porque de ellos sabemos a través del formulario que se incluyen en las fuentes, cómo quedaron reflejados en el documento.

De auenencia que fazen muchas Sepan los que esta carta vieren que antel vegadas ricos omes, o caballeros, o rey vinieron aquellos que fueron...que les otros omes entre sí... si ellos vinieren pidieron merçed, que les otorgasse auenidos, e pidieren merced al rey ${ }^{19}$. aquella auenencia $^{20}$.

\footnotetext{
${ }^{15}$ Cfr. P.3-18-32.

${ }^{16}$ Vid. [A]rchivo [H]istórico [N]acional, Órdenes Militares, Calatrava, Carpeta 424, $\mathrm{n}^{\mathrm{o}} 103$.

${ }^{17}$ Vid. A.H.N. Diversos. Concejos y Ciudades, leg. 75 "Niebla".

${ }^{18}$ Vid. [A]rchivo [C] atedral de [S] evilla, Caja $18, \mathrm{n}^{\mathrm{o}} 1$.

${ }^{19}$ Cfr. P.3-18-15.

${ }^{20}$ Ibidem.
} 


\begin{tabular}{|l|l|}
\hline $\begin{array}{l}\text { Peticiones fazen los omes con cartas } \\
\text { del apostólico... e demandan al rey } \\
\text { cartas }^{21} \text {. }\end{array}$ & $\begin{array}{l}\text { Sepan que el rey manda, que tal obispo o } \\
\text { tal abad... que pidió merced al rey, que } \\
\text { tal petición anduviese por sus reynos }\end{array}$ \\
\hline
\end{tabular}

Resulta evidente, pues, que una posible distinción entre dos de las formas en las que se pueden dirigir los súbditos al monarca: petición y demanda, quedan reflejadas en la conscriptio documental bajo la forma clara de petición, sin hacer, como hemos dicho antes, distinción entre ambas formas.

La petitio aparece recogida en distintas partes del tenor documental. Así la encontramos reflejada en el expositivo:

Del rey a aquellos que mandan fazer la pesquisa como les faze saber... de que pide merced al rey que sepa la verdad ${ }^{23}$.

Porque el conçeio de Sant Esteuan de Asnatoraf nos enviaron pedir merçed que aquella franqueza que auíen los de Vbeda de... que gela otorgemos así commo la ellos auíen ${ }^{24}$.

E pidíonos por merçed donna Teresa Pérez, la sobredicha quel confirmássemos la donación quél fizo su marido, por nuestra carta plomada ${ }^{25}$.

Bien, simultáneamente en el expositivo y dispositivo:

...Ramón Pérez vino ante nos Don Alfonso... e pidíonos merced, que legitimásemos a Remondo, su fiio... Onde nos, queriédole fazer bien e merced, cumplimos su ruego e legitimamos ${ }^{26}$.

O más raramente en la data del documento:

Dada en Seuilla, el rey la mandó por ruego del electo e del arçobispo sobredichos, dos días... ${ }^{27}$.

\subsection{Interventio}

A la petitio puede acompañar, casos si, casos no, la interventio. En ella, una persona de alta dignidad o bien un miembro de la familia del rey, efectúa una es-

\footnotetext{
${ }^{21}$ Cfr. P.3-18-21.

22 Ibidem.

${ }^{23}$ Cfr. P.3-18-24.

${ }^{24}$ Vid. [A]rchivo [D]ucal de [M]edinaceli, Santisteban, leg. 1, no 19.

${ }^{25}$ Vid. A.C.S. Caja 119, no 98.

${ }^{26}$ Vid. P.3-18-9.

${ }^{27}$ A.C.S. Caja $133, n^{\circ} 6 / 1$
} 
pecie de "recomendación legal" para avalar, en la medida de lo posible, la petición efectuada al monarca.

Esta interventio ha dejado huellas en la documentación a través de fórmulas que reflejan la intención "por ruego" del interviniente. Dos matizaciones al respecto. En primer lugar, que la terminología interviniente va referida a la participación de una persona en la actio documental, simplemente como aval del peticionario. En segundo lugar, que no debe confundirse con la figura jurídica que en la alta Edad Media se conocía por esa denominación y que con su sola presencia validaba el acto $^{28}$.

Las fuentes legales alfonsíes recogen numerosos ejemplos de esta interventio:

E deue y fazer mención, como le faze aquel quitamiento, por fazerle bien e merced, o por seruicio que le fizo, o por ruego de fulano que rogó por é $1^{29}$.

E deue decir en ella si le perdona por ruego de alguno ${ }^{30}$.

La interventio aparece reflejada en el tenor documental de la documentación alfonsí en el expositivo:

E nos, el sobredicho rey don Alfonso, por ruego de don Luys, nuestro hermano, e por sabor que auemos de fazer bien e mercet a Garci Martínez, el sobredicho... ${ }^{31}$.

Hasta ahora hemos hecho alusión a dos momentos importantes de la actio documental: la petitio y la interventio. Su protagonismo radica en el hecho de constituirse en un eslabón importante para la posterior redacción del documento, pero que, en modo alguno, esta importancia ni puede ni debe embargar, el proceso encauzado a la ejecución de la conscriptio documental. Por eso hemos optado en calificar a ambas como eslabones importantes pero no imprescindibles. Porque nos podemos encontrar y de hecho nos encontramos, con documentos cuyos primeros pasos de la génesis documental ni constan ni han existido, ya que provienen de actos que emanan de la directa voluntad del monarca, sin que haya existido ni petitio, ni interventio alguna ${ }^{32}$.

\footnotetext{
${ }^{28}$ Vid. A. PRATESI, Genesi e forme, pp. 38-39.

${ }^{29}$ Cfr. P.3-18-10.

${ }^{30}$ Cfr. P.3-18-12.

${ }^{31}$ Vid. Archivo de la Catedral de Córdoba, c.p., $n^{\circ} 238$.

${ }^{32}$ Vid. A. PRATESI, Genesi e forme, p. 36.
} 


\subsection{Consensum}

En ocasiones en los documentos nos aparecen personas un tanto extrañas a la esencia del negocio jurídico contenido en ellos, pero que por preceptos legales tenían que intervenir en los mismos.

La participación de estas personas, pues, quedaba ajustada a los preceptos legales que reglamentaban la redacción de un documento. Precisamente su diferencia con el anterior estadio - la interventio - radica ni más ni menos que en su postura ante la legalidad de una y otra. Así, mientras que la interventio no es ni puede ser requisito imprescindible, ni desde el punto de vista de la actio documental, ni desde el punto de vista del precepto legal; el consensum, por otra parte, necesariamente ha de ser de la actio, siempre y cuando esté condicionado por las normas legales de la emisión de ciertos tipos diplomáticos de la cancillería regia.

Así, por ejemplo, en la emisión de los privilegios rodados era preceptivo el consensum de la reina e hijos, así como de los condes, prelados y personas adscritas a la casa regia ${ }^{33}$. Precepto que, indudablemente, para cualquier persona conocedora de la documentación bajomedieval castellana recordará con prontitud y con una amplia gama de variedades en cuanto a las dignidades se refieren; y que aparecen mencionadas en la larga lista de confirmantes que aportan su consensum al negocio jurídico del documento ${ }^{34}$.

La misma afirmación, pero en sentido contrario, podemos anotar al referirnos a la emisión de las cartas plomadas, donde resulta preceptivo la no presencia de reina e hijos, amén de la larga lista de confirmantes ${ }^{35}$.

Así pues, la presencia fluctuante de este momento de la actio documental - consensum - está en función de los preceptos legales y normas vigentes en la oficina de expedición de documentos.

${ }^{33}$ Vid. P.3-18-2. Otro tema a dilucidar será el de comprobar la efectiva presencia de todos estos personajes en la corte mientras que se otorgaba y se redactaba el documento. A nuestro entender creemos que se trata más de una práctica burocrática ajustada a preceptos legales que a una presencia física y efectiva de todos ellos en los momentos de otorgar, redactar, validar y expedir el documento.

34 Omitimos intencionadamente la trascripción de estas amplias listas de confirmantes en el texto porque sólo conducirían a llenar líneas inútiles, por cuanto el lector las podrá visualizar en los privilegios rodados emitidos por la cancillería.

${ }^{35}$ Vid. P.3-18-4. Remitimos a las mismas razones expuestas en la nota anterior. 


\subsection{Otorgatio}

Tras el consensum, el beneplácito del rey a la acción a él pedida, o del acto emanado de su propia voluntad, da lugar al otorgamiento del monarca y por consiguiente dirige su orden al notario o al escribano para que proceda a elaborar material y normativamente el documento

E nos el sobredicho rey don Alfonso... otorgamos esta donación e confirmámosla por esta nuestra carta ${ }^{36}$.

Et yo sobredicho rey don Alffonsso otorgo esta carta ${ }^{37}$.

Este último momento de la actio da paso a la conscriptio.

\section{2.- CONSCRIPTIO}

El desarrollo de la conscriptio lo vamos a dividir en dos fases: conscriptio documental y conscriptio cancilleresca, cuyos límites se encuentran en el pase del documento, ya redactado, a la cancillería para que proceda a su cancelación o validación ${ }^{38}$.

Alfonso X concibe a la cancillería como un mecanismo de centralización y de intervencionismo regio a ultranza, en torno al documento que en su época se había convertido en imprescindible para el funcionamiento de la maquinaria administrativa de sus reinos. Las fuentes legales alfonsíes definen a la cancillería como:

Es lugar do deuen aduzir las cartas para sellar, e aquellos que lo ouieren de ver, déuenlas catar, e las que non fueren bien fechas, déuenlas romper, e quebrantar; e las que fueren fechas derechamente, déuenlas mandar sellar. E por esto la llaman cancellería, porque en ella se deuen quebrantar, e cancelar las cartas que fueren mal fechas ${ }^{39}$.

Sin embargo, el ámbito de actuación de la cancillería fue mucho más amplio que el que aquí se contempla. La definición que da la Comisión Internacional de

\footnotetext{
${ }^{36}$ Vid. A.C.S. Caja $114, \mathrm{n}^{\mathrm{o}} 23$.

${ }^{37}$ Vid. A.H.N. Clero, Carpeta 286, $\mathrm{n}^{\circ} 20$.

38 Remitimos a las puntualizaciones que efectuamos al iniciar la exposición acerca de la conscriptio documental y conscriptio cancilleresca. Sólo indicar que en nuestra exposición vamos a seguir el camino más largo que nos podemos encontrar en esta fase de la conscriptio, pero que a su vez resulta ser el más completo. Nos referimos a aquellos documentos - caso de los privilegios rodados - que manda el rey elaborar a sus escribanos.

${ }^{39}$ Vid. P.3-20-6.
} 
Diplomática se adecua más a lo que fue la cancillería de Alfonso X: "Est un organe du gouvernement d'un Etat, une institution d'administration publique, éventuellement un service d'une personne morale, qui est chargée de la rédaction, de la mise par écrit et de la validation des actes qui lui sont commandés par l'actorité dont il dépend. La chancellerie este le plus souvent responsable de tout ce qui concerne l'expedition des actes (enregistrement, publication, perception des taxes, etc." 40 .

Para lograr su objetivo concibe la idea de una gran oficina - la cancilleríaque se nos presenta con dos misiones fundamentales. Una, la de ser emisora de todos y cada uno de los documentos que se escriben para la gobernación del reino; y otra, la de ser receptora de aquellos otros documentos que de cualquier procedencia se enviaban al rey o a los órganos de administración del reino.

Por lo que hace referencia a la primera misión, se convierte en la única oficina que posee los sellos del rey y consiguientemente, la única que está facultada para validar los documentos que a ella se llevan con cualquiera de los sellos que custodia y que, según normas de cancillería resultaba preceptivo colocarle. Antes de ser sellado el documento era examinado por el propio canciller - o persona que realizaba sus funciones - y registrado en los libros-registros por los escribanos afines. Se vuelve, pues, a la idea etimológica del término cancillería - cancellare - que es la que recogen las fuentes y que ya se usó en el reino de León, durante el reinado de Alfonso IX ${ }^{41}$.

En cuanto a la segunda misión, se convierte en la oficina receptora de los documentos llegados hasta ella. Las fuentes preceptúan que los escritos del rey los debe guardar su camarero ${ }^{42}$.

El núcleo central de la cancillería estaba constituido por el canciller, los notarios, los escribanos: grossatores y registratores y los selladores.

El deseo centralizador trajo consigo la existencia de una serie de oficinas anexas en las que tenía lugar la redacción de documentos que posteriormente eran llevados a la cancillería, propiamente dicha, para su examen, registro y validación. Estas oficinas que comienzan a pergeñarse son esencialmente tres: las notarías

${ }^{40}$ Cfr. DIPlOMATICA ET SIGILlogRAPHICA, Folia Caesaraugustana, I, Zaragoza, 1984, p. 145 [Folia Caesaraugustana].

${ }^{41}$ Vid. J. GONZÁLEZ, Alfonso IX. Colección Diplomática (1188-1230), 2 vols., Zaragoza, 1944. En especial vol. I, pp. 479-564.

${ }^{42}$ Este hecho no debemos perderlo de vista porque en ella — la cámara del rey — se gestará la futura secretaría de cámara y cancillería de la poridad. De forma voluntaria hemos omitido el resto de cancillerías calificadas como menores como son: la cancillería de la poridad, la cancillería de la reina y las cancillerías de los infantes. 
mayores y los oficios de justicia y cámara. Localizadas todas ellas dentro de la corte itinerante del monarca pero diferenciadas por su función, si bien, por la propia idiosincrasia de la organización de la corte, aparecen escribanos que redactan sus documentos para varias oficinas ${ }^{43}$.

Las notarías mayores fueron tres: una para León, otra para Castilla y otra para Andalucía. En cada una de ellas figura un notario de: León, Castilla y Andalucía y un número indeterminado de escribanos, a cuyo cargo corría la redacción de documentos fundamentalmente de merced, gracia y gobierno.

La oficina correspondiente al oficio de justicia estaba presidida por los alcaldes de corte, a cuya jurisdicción se encuentran notarios y escribanos. Se encargaban fundamentalmente de la redacción de documentos tocantes a la administración de justicia.

Finalmente, en cuanto al oficio de cámara, a su frente se encuentra el camarero del rey y la integran notarios y escribanos que tienen como misión el despacho de documentos de tipo económico.

\subsection{Conscriptio documental}

Se inicia desde el preciso momento en que el monarca directamente o a través del notario "ad verbum" o "per notam" ordena que se confeccione el documento; y concluye con la registración del mismo en el libro-registro del funcionario que lo redactó. Se desarrolla en los siguientes momentos documentales: iussio, minutatio, grossatio, recognitio notarii, vista y registratio scriptoris. Una vez concluida esta fase, el documento pasa al núcleo central de la cancillería para proceder a su cancelación o validación definitiva. A cada uno de estos momentos nos referimos a continuación.

\subsubsection{Iussio}

Supone el inicio de la conscriptio documental. Es el momento preciso en el que la acción jurídica comienza a plasmarse en la elaboración formal de los documentos. Las fuentes legales alfonsíes - Espéculo y Partidas - son bastante precisas a la hora de designar cuáles son las personas que se encuentran facultadas

\footnotetext{
${ }^{43}$ No hay que perder de vista que el concepto de "oficina" se conforma más en la función que desarrolla y no en los autores materiales de sus documentos. Asistimos a la época de su gestación y además en una ciudad ambulante como era la corte itinerante.
} 
para ejercer esta iussio: el rey ${ }^{44}$, el canciller ${ }^{45}$, el notario ${ }^{46}$ y los alcaldes de corte ${ }^{47}$. Precisamente el rey como intitulante de los documentos, dos de sus oficiales de la poridad: el canciller y el notario; y uno de sus oficiales para la administración de justicia: los alcaldes de corte.

Ciñéndonos a la figura del rey, nos aparecen fórmulas que constatan esta iussio regia:

Aquel rey que lo manda fazer en uno con su mujer de bendición ${ }^{48}$.

Sepan todos los concejos, e todos los omes que esta carta vieren, que el rey que la mandó fazer ${ }^{49}$.

Como puede comprobarse, utiliza el verbo mandar, para ejercer la iussio documental. Esta - la iussio - queda reflejada tras la indicación de la fecha tópica y en la suscripción del escribano que, valga la redundancia, "escribió" el documento:

E de si deuen escreuir en él, como es fecho por mandado del rey ${ }^{50}$.

E deue decir en cada una destas cartas, como la faze por mandado del rey... ${ }^{51}$

Yo, Iohán Domínguez la escreuí por mandado del rey ${ }^{52}$.

Antes hemos dicho que la iussio podían ejercerla, aparte del rey, otros oficiales de su corte, caso del canciller, notarios y alcaldes de corte. Pues bien, cuando estos oficiales aparecen ejerciendo la iussio documental, ésta se hace constar bien en la suscripción del escribano, bien tras la indicación de la data en aquellos documentos en los que se omite el nombre del escribano. Previamente, en ambos casos se ha hecho constar en la data de los documentos que fueron "fechos" o "dados", "por mandado del rey", dando lugar, pues, a una iussio delegada que

${ }^{44}$ Vid. P.2-9-8; P.3-18-3; P.3-20-3.

${ }^{45}$ Ca maguer el rey e el chanceller, e el notario, manden fazer las cartas en poridad. Cfr. P.2-9-8. Incluso, las fuentes alfonsíes resultan mucho más explícitas cuando afirman que el canciller: non puede dar por si privilegio, nin carta de gracia, nin notarla, nin mandarla fazer, sin mandado del rey. Cfr. P. 4-18-13. Vid. también, P.3.20-3.

${ }^{46}$ Vid. P.2-9-8; P. 3-18-3; P.3-20-3.

${ }^{47}$ E que non sellen carta ninguna, si non dixere en ella que la manda fazer el rey, canceller, o notario, o alcalde... Cfr. P.3-20-3.

${ }^{48}$ Cfr. P.3-18-2.

${ }^{49}$ Cfr. P.3-18-6.

${ }^{50}$ Cfr. P.3-18-2.

${ }^{51}$ Cfr. P.3-18-4

${ }^{52}$ Vid. A.D.M., Cogolludo, leg. 2, n ${ }^{\mathrm{o}} 7$. Los ejemplos en este sentido podrían multiplicarse. 


\section{ANTONIO J. LÓPEZ GUTIÉRREZ \\ LA GÉNESIS DOCUMENTAL EN LA CANCILLERÍA REAL DE ALFONSO X}

partiendo de la persona del rey se derrama sobre aquellos funcionarios que se encuentran facultados para ejercerla. Veamos algunos de estos ejemplos:

Don Pelay Pérez, chanceller del rey e abad de Valladolid, que lo mandó fazer por mandado del rey ${ }^{53}$.

Fecha la carta... por mandado del rey...; Iohán Ferrández de Segouia la escriuió, por mandado del don Garci Martínez, notario del rey ${ }^{54}$.

Dada en... el rey la mandó...; Fernán Ferrández la fizo por mandado del Maestre Iohán Alfonso, notario del rey e arcidiano de Sanctiago ${ }^{55}$.

Dada en..., el rey la mandó...; Alfonso Martínez la fizo por mandado de don García Pérez, notario del rey ${ }^{56}$.

Dada en... el rey la mandó...; Iohán Iohannez la fizo por mandado de Miguel Fernández, alcalde del rey ${ }^{57}$.

Dada en... por mandado del rey...; Iohán Pérez de Berlanga la escriuió por mandado del arcidiano maestre Ferrando e del arçidiano don Suero ${ }^{58}$.

Aparte de estos oficiales designados en las fuentes alfonsíes y que han sido constatados con la documentación, nos han aparecido otras personas que por su relevancia en la corte unas, y por su significación en orden a la historia de la administración española otras, resulta obligada su inclusión:

Dada en..., el rey la mandó...; Iohán Ferrández la fizo por mandado de don Alfonso, fijo del rey ${ }^{59}$.

Dada en..., el rey la mandó...; Marcos García la fizo por mandado de Pedro Lorenzo, arcidiano de Cádiz ${ }^{60}$.

${ }^{53}$ El documento contiene una concesión a la Orden del Temple de la posesión de Jerez de los Caballeros y Fregenal, prometiéndole confirmar los privilegios que la Orden tuviera tanto de él como de sus antecesores. Publicado por SANCHEZ CID: Epitome histórico de la villa de Fregenal, pp. 90-93. El documento fue expedido en Sevilla el 8 de marzo de 1283.

${ }^{54}$ Vid. A.H.N. Órdenes Militares. Uclés, Carpeta 50-1, no 3.

${ }^{55}$ Vid. Archivo del Monasterio de Carrizo, $\mathrm{n}^{\mathrm{o}} 327$.

${ }^{56}$ El documento expedido en Vitoria, el 5 de enero de 1256 contiene una autorización de Alfonso X para que todos aquellos que lo deseen puedan comprar propiedades a los moros de Arcos. Publicado en Memorial Histórico Español, I, p. 81. Cit. A. BALLESTEROS BERETTA, Itinerario, p. 147.

${ }^{57}$ Vid. A.H.N. Órdenes Militares. Calatrava, Carpeta 424, nº 103.

${ }^{58}$ Vid. A.C.S. Caja 5, no 46/1.

${ }^{59}$ Vid. A.H.N. Diversos. Concejos y Ciudades, leg. 48.

${ }^{60}$ El documento expedido en Sevilla, el 1 de julio de 1261, va dirigido a todos los concejos del arzobispado de Sevilla, comunicándoles que le ha sido concedido a la iglesia de Sevilla, un dezmero de cada iglesia de ese arzobispado. Vid. A.C.S. Caja 14, nº 6/1 (sig. Antig. 45-3-9). 
Yo, Sancho Pérez, notario de la cámara del rey, arcidiano de Baeça, la fiz escreuir por mandado del rey ${ }^{61}$.

En otros casos, el examen de la iussio en la documentación consultada nos ha puesto de manifiesto un hecho de especial relevancia: comprobar el grado de burocratización que va alcanzando la maquinaria estatal durante estos años. Así vamos a contemplar el ascenso de algunos escribanos que trabajaban junto a la persona del rey, al cargo de notarios, tal es el caso de Millán Pérez de Aellón. También, cómo esta iussio en principio delegada por el monarca vuelve a serlo, ahora por la persona que la recibió por parte del rey a otro oficial de la cancillería. Y por último, la presencia de unos "tenientes de veces" de los notarios. Veamos algunos de estos ejemplos:

Fecha la carta..., por nuestro mandado...; Gil Martínez de Sigüença la escriuió por mandado de Millán Pérez de Aellón... ${ }^{62}$.

Don Gonçalo, obispo de Cuenca e notario del rey, la mandó fazer por mandado del rey. Yo, Roy Martínez la fiz escreuir ${ }^{63}$.

Iohán Rodríguez la mandó fazer por mandado del rey. Yo Iohán Pérez la fiz escreuir $^{64}$.

Maestre Pedro, arcidiano de la reyna e teniente las vezes de maestre Iohán Alffonso, notario del rey e arcidiano de Sanctiago, la mandó fazer por mandado del rey ${ }^{65}$.

Esta delegación de la iussio ha dejado constancia gráfica entre el scribi feci y el scribi, apareciendo una o dos manos dentro del documento. En el primer caso, la escritura del texto no coincide con la del notario; y en el segundo caso, del que contamos la mayor parte de ejemplos, no presenta diferencias escriturarias entre una y otra.

Martina Klein alude a que la mencionada diferencia de letra o tinta - elemento diferenciador introducido por la citada autora - entre el tenor documental y la suscripción cancilleresca no siempre es verificable en todos los casos

${ }^{61}$ Vid. A.H.N. Órdenes Militares. Diversos. Concejos y Ciudades, leg. $\mathrm{n}^{\mathrm{o}} 75$.

${ }^{62}$ Vid. A.C.S. Caja 116, $\mathrm{n}^{\circ} 25$. Los ejemplos podrían, igualmente, multiplicarse.

${ }^{63}$ Ibid. Caja $18, \mathrm{n}^{\circ} 1$.

${ }^{64}$ Ibid. Caja 3, no 16.

${ }^{65}$ El documento contiene una prohibición a los vecinos de Murcia para que no metan vino de fuera en la ciudad, ni que aprovechando la feria aumenten el precio del vino. Está expedido en Murcia, el 12 de septiembre de 1271, y está publicado por A. BARRIOS, Archivo Municipal de Alba de Tormes, $\mathrm{n}^{\circ}$ 12, pp. 50-51. 
en que fue utilizada la locución "hacer escribir" y para constatarlo alude a tres documentos conservados en el Archivo Municipal de Murcia ${ }^{66}$.

En dicho Archivo se conservan cuatro documentos en los que se hace constar la presencia de Bonamic $^{67}$ y corresponden a los números 31 bis, 34, 35 y 36 del mencionado repositorio. De ellos los $n^{\circ} \mathrm{s} 31$ bis y 36 están confeccionados por Bon Amic tal y como se hace constar en sus respectivas suscripciones de cancillería: "Yo, Bon Amic, la escriuí por mandado del rey" y por lo tanto ambos documentos fueron redactados por su mano. Los documentos n's 35 y 34 contienen en su suscripción: "Yo, Bon Amic, la fiz escreuir por mandado del rey", es decir, documentos presumiblemente redactados por dos manos. Ahora bien, la citada autora en base a la tinta de estos dos últimos documentos afirma que el doc. $\mathrm{n}^{\mathrm{o}} 35$ "la cláusula de cancillería presenta un color visiblemente más claro que el tenor del documento" 68 . En cuanto al documento $\mathrm{n}^{\circ} 34$ "pese a que la tinta está algo borrosa — desvaída en término de conservación documental-parece haber una perfecta continuidad de la escritura en todo el diploma -entiendo que se refiere al tipo de escritura utilizado- lo que podría indicar que es un producto de una misma pluma... ${ }^{69 ، . ~ S i g u e ~ l a ~ c i t a d a ~ a u t o r a: ~ " P o r ~ l o ~ t a n t o, ~ s i ~ b i e n ~ " h a c e r ~ e s c r i b i r " ~}$ puede tener un sentido ambiguo con relación a la acción efectivamente realizada, "escribir" parece no dejar duda de que invariablemente indica la autoría material del documento..." $"$. Y concluye: "Reiteramos, por tanto, la conclusión de que las tres expresiones utilizadas en las suscripciones cancillerescas por individuos claramente identificados como escribanos del rey —nombradamente "escribir", "hacer" y "hacer escribir" - señalan el desempeño de la función de redactar los documentos de Alfonso X $y$, por consiguiente, la responsabilidad material sobre la confección de los mismos"71.

En modo alguno la clave de la adjudicación material de un documento a su autor se encuentra en la tinta utilizada sino esencialmente en un análisis paleográfico de sus caracteres gráficos para ir identificando el número de manos escribanos - que trabajaron en la cancillería regia de Alfonso X.

\footnotetext{
66 Vid. M. KLEIN, La cancillería real de Alfonso X: actores y prácticas en la producción documental, Sevilla, 2015, pp. 103-105 [Actores y prácticas].

${ }^{67}$ Sobre la figura de Bonamic, puede consultarse el trabajo de I. GARCÍA DÍAZ, "Bonamic y el traslado de la Diócesis de Cartagena en el siglo XIII”, Carthaginensia, XXXI (2015), pp. 89110 que recoge una amplia bibliografía sobre este personaje.

${ }^{68}$ Vid. M. KLEIN, Actores y prácticas, p. 104.

${ }^{69}$ Ibidem.

${ }^{70}$ Ibid., pp. 104-105.

${ }^{71}$ Ibid., p. 105.
} 
La citada autora, en el trabajo anteriormente mencionado, manifiesta haber manejado 1.931 documentos expedidos por la cancillería y de ellos sólo uno evito facilitar porcentajes- parece ser que no se ajusta a lo marcado por las normas de cancillería. Además, dicho documento se trata de una carta abierta, la de menor rango de los expedidos en la cancillería alfonsí, conteniendo un mandato.

En base a este hallazgo, presenta una serie de conclusiones relativas a las expresiones "escriui" y fize escriuir" que en modo alguno se corresponden con la doctrina general contenida en los manuales clásicos de Diplomática y que la citada autora convierte en regla lo que es una excepción con escasa o nula representatividad. Podría calificarse el documento como atípico, al igual que tantos otros expedidos por la cancillería de Alfonso X, pero nunca como base doctrinal para explicar el ejercicio de la iussio y la confección material del documento.

Volviendo de nuevo a la iussio ejercida directamente por el rey, ésta podía efectuarse de dos formas bien distintas: una "ad verbum", es decir de palabra ${ }^{72}$ dirigida directamente al escribano; otra "per notam", dando lugar, en este último caso, a una nueva fase de la conscriptio documental: la minutatio.

\subsubsection{Minutatio}

Consiste en la elaboración de una nota que era entregada al escribano por parte del rey, bien por parte del notario ${ }^{73}$. Las fuentes alfonsíes recogen que las notas: "eran realizadas por los notarios tanto para los privilegios como para las cartas" 74 .

El término "nota" ha de entenderse sinónimo de minuta en el sentido preceptuado por el Codex Iustiniano: scheda conscripta ${ }^{75}$; en el sentido también, que lo definen Du Cange ${ }^{76}$. En definitiva, la definición que recoge el Comité Internacional de Diplomatica al identificar a la minuta como: "la premiére redaction d'un acte, dont le texte est établi ne varietur de telle façon qu'il puisse servir de matrice à l'expédition de l'acte er à d'eventuelles réexpeditions. Elle est général-

\footnotetext{
${ }^{72}$ Conplir debe el escribano lo que dixiemos en la ley antes desta, e después que lo oviere conprido, así como en esta ley mostramos, debe lo levar al notario, que vea si es fecho segunt la nota quél dio el rey o el notario, ol dixieron por palabra. Cfr. P.3-18-3; E.4-12-14.

${ }^{73}$ Ibidem.

${ }^{74}$ Cfr. P.2-9-7.

${ }^{75}$ Vid. Códex Iustiniano, IV, 21. De fide instrumentorum. Cit en A. de BOUARD, Manuel de Diplomatique Française et Pontificale. 2 t. et álbum, París, 1929-1948, p. 82.

${ }^{76}$ Vid. Ch. DU CANGE, Glosarium mediae et infimae latinitatis, IV, St. Graz, 1954, p. 404 [Glosarium].
} 
ment allégée des formules de style et peut ne comporter qu'une simple indication de la présence de clauses qui figureront au long sur l'expedition"77.

La redacción de la nota era personal y no existía ningún tipo de delegación hacia otra persona para que la confeccionara; caso contrario de lo que acontecía, como más adelante indicaremos, con la grossatio de los escribanos.

Carecemos de noticias sobre el formulario de estas notas, a través del examen de las fuentes legales alfonsíes consultadas y de los propios documentos manejados. Lo más probable es que, por la índole misma de las notas, no se ajustasen a un formulario concreto. No se han conservado, como ocurre en otras cancillerías, registros algunos de minutas $^{78}$.

Una vez que la nota estaba confeccionada el rey o el notario la entregaba al escribano para que procediera a su "escritura".

\subsubsection{Grossatio}

Este momento documental corre a cargo de los escribanos del rey. Con la nota en su poder en la que se le consignaban: los datos más esenciales del documento a emitir, las precisiones jurídicas pertinentes, las formas documentales a usar — según la práctica cancilleresca - y naturalmente, teniendo a su alcance formularios documentales ${ }^{79}$, junto con las propias normas que sobre documentación emanaban de las fuentes legales alfonsíes, el escribano redactaba "in extenso" el documento ${ }^{80}$. Es, en resumen, el instante en que el escribano elige el soporte gráfico y tipo de escritura a emplear, de acuerdo, con el contenido de la nota a él entregada.

Esta labor de redactar el documento "in extenso" debía efectuarla en el más amplio sentido del término, evitando cualquier intento de escribir alguna palabra mediante abreviaturas, en particular aquellas que pueden inducir a error o falsedad. Nos referimos en concreto a los nombres de personas, de lugares, cantidades pecuniarias y en la era de los documentos:

\footnotetext{
${ }^{77}$ Cfr. Folia Caesaraugustana, p. 158, no 313.

${ }^{78}$ Vid. J. TRENCHS ODENA, Diplomatario del Cardenal Gil de Albornoz. Cancillería Pontificia (1351-1353), Barcelona, 1976, p. XXXIV.

${ }^{79}$ En esta línea de formularios de cancillería puede inscribirse la obra de V. BERTOLUCCIPIZZORUSSO, "Un Trattato di "Ars Dictandi"dedicato ad Alfonso X", Studi Mediolatini et volgari, XV (1967), pp. 3-83.

${ }^{80}$ Puede consultarse a tal efecto la rotunda aseveración que referida a este aspecto realizan las fuentes: "cumplir deue el escriuano lo que diximos en la ley antes desta", refiriéndose a la confección del privilegio rodado. Cfr. P.3-18-3. Similares afirmaciones en P. 3-18-2 a P.3-18-25.
} 


\section{ANTONIO J. LÓPEZ GUTIÉRREZ \\ LA GÉNESIS DOCUMENTAL EN LA CANCILLERÍA REAL DE ALFONSO X}

E esto es, que en los preuillejos, e en las cartas que fizieren, en qual manera quier que sea, que non pongan vna letra por nombre de ome, o de su mujer, así como A. por Alfonso; nin de los nombres de los lugares, nin en cuenta de auer, o de otra cosa, así como C. por ciento: esa misma guarda deue auer en la era ${ }^{81}$.

Caso de que el escribano redactase el documento no observando lo preceptuado por la legislación, el documento podía ser declarado nulo, y además el daño que pueda sufrir la parte por esta anomalía debía ser reparada por el propio escribano que lo confeccionó ${ }^{82}$. Que esta normativa no se cumplió s evidente por los ejemplos que acompañamos.

Iohan Pérez de Berlanga la escriuió por mandado del arcidiano maestre Ferrando e del arçidiano don Suero, era de mille e CC e LXXXXI anno ${ }^{83}$.

Fecha la carta en Seuilla, por mandado del rey, XXV días de deziembre, era de mil e CC e nouaenta e vn anno. Pedro Pérez de Segouia la escriuió... ${ }^{84}$

Dada en Medina del Campo, el rey la manda XX días de iunio, era de MCC e nouaenta e tres annos. Iohán Iohannes la fizo... ${ }^{85}$

A tenor de lo que preceptuaban las fuentes legales, el autor material del documento debía colocar al final del privilegio: "el nombre del escriuano que la fizo" 86 .

Esta aseveración que realizan las fuentes legales debemos admitirla con ciertas reservas ya que, según se desprende de las etapas en las que dividimos la cancillería regia de este periodo ${ }^{87}$, hasta 1259 la inclusión del nombre del escribano - autor material del documento - en el protocolo final es prácticamente constante, no sólo en los privilegios rodados sino también en el resto de los tipos documentales ${ }^{88}$; es también frecuente para este periodo ver cómo en la plica de los documentos aparecen unas marcas a modo de símbolos que a nuestro entender, en algunos casos, sintetizan el nombre del escribano, formando un triple nexo con sus siglas ${ }^{89}$. De 1259 a 1275 la inclusión de su nombre resulta fluctuante bien en

${ }^{81}$ Cfr. P.3-20-7.

${ }^{82}$ Ibidem.

${ }^{83}$ Vid. A.C.S. Caja 5, no 46/1.

${ }^{84}$ Ibid., Caja $101, \mathrm{n}^{\circ} 25$.

${ }^{85}$ Vid. A.H.N. Órdenes Militares, Calatrava, Carp. 424, nº 103.

${ }^{86}$ Cfr. P.3-18-2.

${ }^{87}$ Vid. A. J. LÓPEZ GUTIÉRREZ, La cancillería de Alfonso X, pp. 192-228.

${ }^{88}$ Los ejemplos al respecto se podrían multiplicar. Vid. Por ejemplo A.C.S. Caja $114, \mathrm{n}^{\mathrm{o}} 19$ y Caja $5, n^{\circ} 46 / 1$.

${ }^{89}$ En concreto la señal $\frac{\text { Sil }}{1}$ la interpretamos como un triple nexo de las iniciales del escribano. Tomando como base de ella la letra "A" (Alvar); sobre ella la letra "G" (García) y formando nexo 
el protocolo final ${ }^{90}$, bien en la parte inferior derecha de la plica ${ }^{91}$. Y de 1275 a 1284 resulta usual la no indicación del nombre del escribano dentro del protocolo final $^{92}$, y fluctuante su inclusión en la parte inferior derecha del documento ${ }^{93}$, o simplemente su no inclusión ${ }^{94}$.

El escribano tenía la obligación de redactar los documentos con sus propias manos ${ }^{95}$ y sólo en aquellos casos que podemos calificar de excepcionales, podía delegar en otros escribanos su elaboración. En este último caso, el escribano sustituto debía colocar al final del documento en la parte correspondiente a la suscripción: "Escriua y su nombre, e como la fizo por mandado del otro ${ }^{96}$. Posteriormente el escribano que efectúa la delegación suscribía con su propia mano tras la suscripción del anterior: "cómo él la mandó fazer" de estas fórmulas era tal que sin ellas el documento redactado podía ser declarado como falso ${ }^{98}$, y consiguientemente su autor incurrir en penas de falsario.

En cuanto a la lengua utilizada en la redacción del documento alfonsí se aprecia un neto predominio de la lengua romance, salvo en contadas ocasiones en las que al dirigirse a personalidades de distintos reinos emplea el latín como lengua de comunicación ${ }^{99}$.

La labor de la grossatio por parte del escribano no se ceñía únicamente a la escritura del documento porque de hecho él también era el encargado de dibujar la

con la "A", la letra "F" (Frómesta). Esta costumbre la vamos a ver de nuevo al final del reinado de Alfonso X, pero indicando su nombre desarrollado sobre la plica. Vid. A.C.S. Caja 101, $\mathrm{n}^{\circ} 20$.

${ }^{90}$ Vid. A.C.A. Caja 181, nº 46.

${ }^{91}$ Ibid., Caja 3, n ${ }^{\mathrm{O}} 13 / 1$.

${ }^{9}$ Ibid., Caja $5, \mathrm{n}^{\circ} 46$.

${ }^{93}$ Ibid., Caja $18, \mathrm{n}^{\circ} 1$.

${ }^{94}$ Los ejemplos que podemos aportar se deben a colecciones diplomáticas publicadas y no a originales consultados por nosotros, de ahí que esta aseveración tengamos que efectuarla con ciertas reservas. Vid. J. L. MARTÍN MARTÍN, Documentos de los Archivos Catedralicio y Diocesano de Salamanca (Siglos XII-XIII), Salamanca, 1977, doc. no 320, pp. 416-417.

${ }^{95}$ E otrosí deuen guardar, que las cartas que les mandaren fazer, que las fagan de sus manos mismas. Cfr. P.3-19-5.

${ }^{96}$ Ibidem.

${ }^{97}$ Ibidem.

98 Resulta evidente que una contropatio realizada entre un documento escrito por un escribano - mano A - y otro documento escrito por otra mano - mano B - , no haciendo constar en uno de ellos las mencionadas fórmulas, conllevaría sin la menor duda a designar a uno de ellos como documento falso. Sobre cartas falsas puede consultarse F.R.2-9-4; E.4.12-46; E.4.12-47; E.4-12-50; P.3-18-11; P.3-18-14.

${ }_{99}$ Vid por ejemplo los documentos publicados por Th. RYMER, Foedera, conventiones, litera et ciuiscumque generis acta publica inter reges Angliae et alios que suis imperatores, reges, pontifices, principes vel communitatis ab inennte saeculo duodecimo, I, Londres, 1740, pp. 509 y 531; II, p. 271. 
rueda de los privilegios rodados, al menos esto es lo que deducimos del cobro de tasas que reciben para gratificar esta labor:

Más estos Escriuanos, que diximos, de la Corte del Rey, mandamos que quien fiziere el preuilleio que tome por galardón vn maravedí por el signo, e por la escritura dél; e por la carta plomada, en que no aya signo, medio marauedí; y por la carta abierta de cuero sellada con cera con el sello mayor, medio marauedí ${ }^{100}$.

Esta hipótesis que recogen las fuentes legales alfonsíes acerca de la posible autoría del signo rodado en los privilegios que lo llevan dibujado, la hemos constatado con algunos de los documentos originales que hemos utilizado para nuestro trabajo. Así podemos determinar que efectivamente hemos encontrado una correspondencia entre el autor material del documento y el signo por él dibujado. Nos referimos, por ejemplo, a los signos realizados por Alvar García de Frómista, Millán Pérez de Ayllón, Gil Martínez de Siguenza, Pedro García de Toledo, entre otros $^{101}$.

Si en cuanto al dibujo del signo en sí, nuestra respuesta es afirmativa, no podemos precisar nuestro aserto acerca de la decoración de los mismos, entre otras cosas porque el método y la técnica para su identificación rebasan los límites propuestos para nuestro trabajo, de ahí que esta hipótesis quede únicamente apuntada.

\subsubsection{Recognitio notarii}

Una vez que la acción ha sido documentada por el escribano, el documento era devuelto al notario para que realizara la correspondiente comprobación de si había sido realizado tal y como le indicaron el rey o el notario de palabra o por nota.

Hay que resaltar que esta primera comprobación se refiere globalmente a los caracteres internos y externos del documento ${ }^{102}$.

\subsubsection{Visa regis}

Acabada la recognitio por parte del notario, éste tenía que presentarle el documento al rey para que lo viera y lo otorgase "por derecho" ${ }^{103}$. Era un requisito

${ }^{100}$ Cfr. P.3-19-13.

101 Vid. M. T. VILLAR ROMERO, Privilegio y Signo Rodado. Madrid, 1964 (resumen de su tesis doctoral inédita).

${ }^{102}$ Vid. P.3-18-5. No consideramos arriesgado suponer que la comprobación se refiriera tanto a los caracteres externos como a los caracteres internos del documento. 
previo para que el documento pudiera ser registrado y posteriormente llevado a cancillería para su cancelación o validación. No debe confundirse, naturalmente, con el concepto de documento "visto" como tradición documental. Se trata para decirlo con palabras actuales, de un "visto bueno".

\subsubsection{Registratio scriptoris}

Cuando el rey devolvía el documento al notario éste se lo entregaba al escribano para que lo registrara en su libro. ¿Qué debe entenderse por esta expresión?

Sin más podría deducirse que el libro del escribano se identificase con los libros-registros de la cancillería. Mucho hemos meditado al abordar este tema de la dualidad: libro-registro del escribano / libros-registros de cancillería. A favor de esta dualidad, por la que nos inclinamos, existen varios testimonios que a nuestro enteder la sustentan de modo incuestionable.

En primer lugar, el Espéculo dice taxativamente:

E si fallase el notario que es así fecho comol dixeron ol mandaron, del al escriuano quel fizo quel registre en su libro, e llevel a la chancillería quel sellen ${ }^{104}$.

Varias cosas a destacar en este texto; si el notario comprueba que el documento se ajusta a la iussio de la conscriptio documental, el escribano ha de registrarlo no en un libro cualquiera sino en su libro. Que registrado que fuera en el libro del escribano, el documento había de pasar a la cancillería para ser sellado,

103 Otrosí estos deuen sellar las cartas, después que el Rey, o el Chanceller las ouieren vistas, e las otorgaren por derechas... Cfr. P.2-9-7. En los últimos años del reinado de Alfonso X, aparecen en los documentos unos personajes, cuyos nombres figuran inmediatamente después de la línea de cancillería, y que suscriben como "visadores". En concreto hemos localizado a Iohán Rodríguez (1279, diciembre 28. Sevilla en A.H.N. Sec. Clero, carp. 1.601, nº 6 bis); Esidro González (1282, mayo 1. Écija en A.M.E. Carp. 1, no 1) y Martín Pérez (1282, agosto 10. Sevilla, en A.M.M.S. Arcón, caja 1, $n^{\circ}$ 5). Estos personajes nos ponen en la evidencia de que, valga la redundancia, visaban los documentos antes de ser expedidos, pero en qué preciso instante de la conscriptio efectuaban esta misión. A nuestro entender nos aventuramos a lanzar la hipótesis de que ello acontecía antes de ser registrado el documento en los libros-registros de la cancillería, porque la fecha de actuación - 1279-1282 - viene a coincidir con la ausencia de los cargos de canciller de Castilla y León representado por los arzobispos de Toledo y Santiago respectivamente. Así mismo, coincide con el ascenso de antiguos notarios - Gonzalo García - y de personas ajenas a la dignidad eclesiástica de arzobispo de Toledo y Santiago, al cargo de canciller. Por consiguiente, a nuestro entender, parece ser que se trata de la confirmación de un hecho que venía aconteciendo desde hace ya bastantes años y que consistía en "visar" el documento por parte del notario dada la ausencia del canciller, y que ahora la realiza otra persona —alguno de ellos también aparecen como notarios - dado que el notario efectivo aparece en estos años desempeñando el cargo de canciller, y consiguientemente la labor recae ahora sobre otros oficiales. Serían a nuestro entender los "visadores".

${ }^{104}$ Cfr. E.4-12-14. 


\section{ANTONIO J. LÓPEZ GUTIÉRREZ \\ LA GÉNESIS DOCUMENTAL EN LA CANCILLERÍA REAL DE ALFONSO X}

de lo que deducimos que al final de la conscriptio documental no era en el registro del libro del escribano sino que para completarla habían de seguirse otros momentos procesales a los que en otro lugar aludiremos. Luego del texto antes citado, podemos deducir que cada escribano tenía un libro para registrar los documentos por él escritos.

No se nos oculta que con sólo este argumento acaso no se podría deducir la dualidad: libro-registro del escribano / libros-registros de cancillería, porque bien podía ocurrir que se interpretase que los registros de cancillería estuviesen constituidos por la suma de los registros de los escribanos, en cuyo caso la fase de registro sería un quehacer cancilleresco no individualizado. Pero esta hipótesis no puede sostenerse ya que el propio Espéculo y en el mismo lugar nos dice:

E el que lo ouiere de sellar fagal escreuir en el registro de la cancillería ${ }^{105}$.

Es decir, atribuye al sellador la función de mandar registrar el documento en un libro distinto del escribano que lo confecionó, es decir, en el registro de la cancillería.

En segundo lugar, en las Partidas, los registradores son definidos como:

Otros escriuanos que ha en casa del rey, que son puestos para escreuir cartas en libros que han nombre registros ${ }^{106}$.

Este texto nos resulta inequívocamente demostrativo de dos cosas: que había dos clases de escribanos (aquí se habla de otros escribanos); y que a distinta clase o categorías de escribanos correspondía también una función diferente: la de éstos era exclusivamente: escreuir cartas en libros que han nombre registro ${ }^{107}$. A este respecto podemos aducir un dato que estimamos significativo: Du Cange dice de los registradores: qui scripturas aut contractus in acta publica referent ${ }^{108}$; $\mathrm{y}$ en apoyo de tal significado aduce el texto de las Partidas anteriormente mencionado.

¿Cuáles eran los registradores que diferencian las Partidas, respecto a los que escriben documentos en los libros que tienen por nombre registros? Sin duda, son aquellos que configuran las fuentes alfonsíes cómo: "Ome que es sabidor de escreuir" 109 , perito en escribir "a secas".

También, en apoyo de la dualidad libro-registro del escribano / libros registros de cancillería, contamos con la nómina del personal de cancillería, entre los

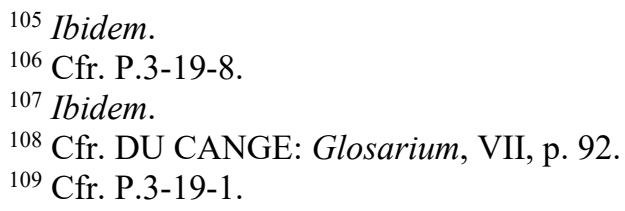




\section{ANTONIO J. LÓPEZ GUTIÉRREZ \\ LA GÉNESIS DOCUMENTAL EN LA CANCILLERÍA REAL DE ALFONSO X}

cuales se distinguen claramente los escribanos de los registradores, como oficio distinto en la fase de la conscriptio documental y de la que hemos llamando conscriptio cancilleresca.

Finalmente todo documento otorgado por el rey debía someterse a la recognitio del canciller en orden a la comprobación de si había sido emitido o no conforme a derecho ${ }^{110}$. Como esta segunda acción — la recognitio - por parte del canciller es posterior a la del registro por el escribano se evidencia lo que venimos comentando.

¿Qué valor pues, tienen estos registros? Pensamos que una función meramente administrativa y casi con toda certeza de su asidua confección se llegó con el tiempo a contar con un material de primera mano para la redacción de los documentos, con lo que adquirirían estos registros un valor de formularios ${ }^{111}$.

Por otra parte, y de acuerdo con las normas de cancillería, el destinatario de la acción jurídica tenía que pagar en concepto de tasa, una cantidad pecuniaria por la expedición del documento. A ella haremos alusión más adelante, cuando nos refiramos a la taxatio. Ahora sólo nos interesa dejar apuntado que de ella, tomaba el escribano una pequeña gratificación en función de la escritura y el signo de cada documento $^{112}$. Interesaba pues, a los escribanos tener constancia de los documentos por ellos redactados y el número de signos rodados dibujados para conocer el cálculo del monto que le correspondía por derechos de confección.

Una vez que el documento ha sido registrado en el libro-registro del escribano, es llevado a cancillería para que lo sellen ${ }^{113}$. A ella - la cancillería- podían llevar documentos para su sellado: el escribano que lo confeccionó o el portero del rey ${ }^{114}$; o bien en los casos concretos de las cartas de poridad, podían llevarlas "alguien" por mandado del rey, o bien, llevada a mano por los notarios ${ }^{115}$.

Una vez que el documento es llevado a cancillería se inicia, para nosotros, la segunda fase a la que hemos denominado: conscriptio cancilleresca.

\footnotetext{
${ }^{110}$ E esto es, porque todas las cosas, que ha de librar por cartas de cual manera quier que sean, han de ser con su sabiduría: e él las deue ver antes que la sellen, por guardar, que non sean dadas contra derecho, por manera que el rey non resciba ende daño nin vergüença. Cfr. P. 2-9-4.

${ }^{111}$ Remitimos a lo dicho en la nota 73.

112 Vid. P.3-19-13.

${ }^{113}$ E si fallare el notario que es así fecho comol dizieron ol mandaron, del al escriuano quel fizo quel registre en su libro, e lievel a la chancillería quél sellen. Cfr. P.3-18-3; E.4-12-14.

${ }^{114}$ Que non tomen carta de mano de otro ome, si non de escriuano, o de portero del rey. Cfr. P.3-20-6; E.4-12-53.

${ }^{115}$ E las cartas de poridad, que dieren a qualquier de los que estuuieren en la cancellería, por mandado del rey, o por mano de alguno de los notarios. Cfr. P.3-20-6; E.4-12-53.
} 


\subsection{Conscriptio cancilleresca}

Comprende desde el preciso instante en que el documento se llevaba a cancillería para que se cancelara o validara, según hemos dicho con anterioridad, hasta el momento en que se valida y está preparado para ser expedido, previo pago de las tasas de cancillería. Los principales momentos que destacamos en esta fase son los siguientes: recognitio cancellarii, registratio cancelleriae, validatio y taxatio.

\subsubsection{Recognitio cancellarii}

Es sin lugar a dudas el momento más importante de la conscriptio cancilleresca por cuanto de su desarrollo y examen del mismo se puede llegar bien a la cancelación definitiva del documento por parte del canciller, o bien hacia el pronunciamiento de la iussio cancilleresca que corría también a cargo del canciller. En este último caso, el documento seguía su iter, iniciándose la registración del mismo.

El canciller tenía la obligación de examinar todos y cada uno de los documentos que bajo la intitulación y otorgamiento del rey llegaban hasta sus manos ${ }^{116}$. La razón de su intervención era bien conocida.

Debe verlas antes de que la sellen para guardar que no sean dadas contra derecho ${ }^{117}$.

A tenor de esta afirmación se puede deducir que incuestionablemente la recognitio cancellarii era esencialmente de fondo - recordemos que la recognitio notarii era de fondo y forma-. Esta recognitio podía dar lugar a un resultado negativo o positivo. En el primer caso pasamos a la cancelatio; en el segundo caso a la iussio cancellarii.

\subsubsection{Cancelatio}

Si el canciller encontraba alguna anomalía en el documento que no fuera redactado según derecho procedía a la cancelación del mismo de dos formas distintas. Una de ellas, consistía en cancelar el documento mediante unos tajos que le

${ }^{116}$ El Espéculo es incluso más conciso al apuntar que: todos los privilegios de cartas qualquier manera que sea por su mano han de pasar. Cfr. E.2-12-2.

${ }^{117}$ Cfr. P.2-9-4. 
proporcionaba al mismo. La otra, consistía en hacerle una serie de trazos con la péñola ${ }^{118}$.

Si el documento se cancelaba por medio de la péñola, le era devuelto bien al escribano, o bien a aquel que lo mandó hacer, para que realizaran la modificación de las anomalías que le han sido encontradas por el canciller ${ }^{119}$. Es pues, una vuelta atrás a la conscriptio documental.

\subsubsection{Iussio cancellarii}

Si por el contrario, el documento había sido redactado de forma y fondo según las normas establecidas en la cancillería, el canciller daba su iussio cancellarii por la cual ordenaba que el documento pasara a ser registrado.

\subsubsection{Registratio cancelleriae}

Corría a cargo de los escribanos-registradores y era un paso previo para su validación. Presuponemos que en cancillería había varios registros, al menos eso es lo que deducimos del contenido tanto del Espéculo como de las Partidas.

E fagan registrar las cartas, cada vna en el registro que le conviniere ${ }^{120}$.

Estos registros, casi con certeza, estaban divididos según áreas geográficas $\mathrm{y}$, probablemente, respondían a la división territorial que tenían los dominios del monarca: Castilla, León y Andalucía ${ }^{121}$.

Esta fase - registratio cancelleriae - podía ser eludida por expreso deseo del rey ${ }^{122}$. De los textos alfonsíes no podemos precisar con exactitud qué tipos de documentos dejaban de pasar por los registros, pero moviéndonos en el terreno de la hipótesis aventuramos que serían aquellos que aún confeccionados en la canci-

\footnotetext{
${ }^{118}$ E si fallase, que alguna y auía, que non fuesse así fecha, déuela romper, e desatar con la péñola. Cfr. P.2-9-4.

${ }^{119}$ E aquellas que rompieren, déuenlas dar a los escriuanos que las fizieron, o aquellos que las mandaron fazer, que enmienden aquello por qué fueron rotas. Cfr. P.3-20-6; E.4-12-53.

${ }^{120}$ Cfr. E.4-13-3; P.3-20-4.

${ }^{121} \mathrm{Al}$ menos sabemos que durante los reinados de Fernando IV y Alfonso XI los registros estuvieron organizados según las circunscripciones geográficas, por lo que suponemos que muy posiblemente ésta sería la organización que tuvieron los registros de cancillería en tiempos de Alfonso X.

${ }^{122}$ E otrosí, que non sellen las cartas antes que sean registradas: fueras ende aquellas que el rey mandare que non registren. Cfr. P.3-20-6; E.4-12-5.
} 
llería tenían consideración de documentos no cancillerescos. En definitiva, no serían registrados sino los documentos considerados como documentos públicos.

El escribano-registrador procedía a: escriuir las cartas como gelas dieren, non menguando nin añadiendo ninguna cosa en ellas ${ }^{123}$. Tomada al pié de la letra esta normativa, el documento sería copiado en los registros "in extenso". Sin embargo, la práctica de otras cancillerías y de la propia cancillería castellana -en los casos en los que se nos han conservado registros- demuestra que los documentos contenidos en ellos eran abreviados en determinadas fórmulas de su protocolo inicial y final, y que por la propia naturaleza de los registros lo que interesaba fundamentalmente, era dejar constancia en ellos del dispositivo. De modo que, el texto que comentamos puede referirse a la transcripción exacta del dispositivo, sin perjuicio de que dada la escrupulosidad de los textos alfonsíes, se tendiera con ello a que en los registros se "insinuaran" los documentos "in extenso" como medida cautelar en orden a la comprobación por parte de la cancillería de los documentos que había emitido.

Este momento de la registratio cancelleriae ha dejado huellas en la documentación alfonsí. Vamos a realizar una distinción en orden únicamente a nuestra "expositio" entre aquellos documentos que nos aportan el nombre del registrador y aquellos otros en los que se nos silencia su nombre.

En el primer caso, junto a su nombre aparece la expresión de haber desempeñado la función de la registración bien sobre la plica: "Martín García, la registró" ${ }^{124}$; bien, al dorso del documento: "Iohán Gonçáluez la registró" ${ }^{125}$; bien, en la parte inferior central del documento, junto al borde mismo de la plica, con unos caracteres gráficos de un módulo menor que el resto de la escritura: "Marcos Pérez, Registrada" 126 .

En el segundo caso, se omite el nombre del registrador pero no la acción que ha realizado. Podemos encontrarnos huellas: en la plica ${ }^{127}$, bajo la plica $^{128}$ o al dorso del documento ${ }^{129}$.

Concluida la labor de registro el documento se encuentra preparado para proceder a su validación.

${ }^{123}$ Cfr. E.4-12-8; P.3-19-8.

${ }^{124}$ Vid. A.H.N. Órdenes Militares, Carpeta 424, $\mathrm{n}^{\circ} 110$.

${ }^{125}$ Ibid. Carpeta 424, $\mathrm{n}^{\circ} 103$.

${ }^{126}$ Vid. A.C.S. Caja $119, \mathrm{n}^{\circ} 98$.

${ }^{127}$ Vid. [A]rchivo [M] unicipal de [S] evilla, Caja $168, \mathrm{n}^{\circ} 1$.

${ }^{128}$ Ibid. Caja $1, \mathrm{n}^{\circ} 5$.

${ }^{129}$ Vid. documento expedido en Toledo, el 4 de mayo de 1254 y que se conserva en el A.H.N. Órdenes Militares, Calatrava, Carp. $423, \mathrm{n}^{\circ} 99$. 


\subsubsection{Validatio}

Tenía lugar tras ser registrado el documento en los libros-registros de cancillería ${ }^{130}$. Esta labor era llevada a cabo por los selladores quienes antes de proceder a su validación invitaban a los registradores a que les mostrasen el documento debidamente registrado porque de hecho no podía sellar documento alguno si con anterioridad no había sido registrado ${ }^{131}$.

Los sellos utilizados por la cancillería alfonsí van a ser los siguientes: sello de oro, sello de plomo y dos sellos de cera: uno pendiente y el otro, placado sobre papel.

En cuanto a su empleo, el sello de oro tal y como recogen las fuentes alfonsíes quedaba reservado para el uso exclusivo del Papa o del Emperador ${ }^{132}$. Todo ello parecía apuntar a que dadas las pretensiones que Alfonso X mantuvo para conseguir la corona imperial, el empleo del sello de oro debe relacionarse con ese asunto. Sin embargo, la realidad documental nos muestra conclusiones bien distintas que pasamos a enumerar. Es cierto que el sello de oro se utilizó para asuntos relacionados con el Imperio ${ }^{133}$, pero también lo es el hecho de haberse utilizado en asuntos totalmente ajenos a él, como lo pone de manifiesto el hecho de los dos documentos conservados en el Archivo Municipal de Sevilla ${ }^{134}$, y otro documento editado por Manuel González Jiménez, relativo al Puerto de Santa María ${ }^{135}$. En todos estos casos en su anuncio de validación se hace constar el hecho de haber sido sellado con el sello de oro. Desgraciadamente, ninguno de estos ejemplares se conserva y su descripción la conocemos a partir de la obra de W. Birch ${ }^{136}$.

El sello de plomo y el de cera pendiente se utilizan por una parte para concesiones, siendo su única diferencia la duración que comporta su concesión. Así,

\footnotetext{
${ }^{130}$ No hay dudas en cuanto a la primacía del registrado antes del sellado del documento. Vid. P.3-20-6; E.4-12-14; E.4-12-53; E.4-13-3.

${ }^{131}$ E otrosi deuen guardar, que non sellen carta ninguna a menos de ser registrada. Cfr. P.3$20-4$.

132 Vid. P.3-18-1.

133 "In cuius rei testimonium presentem cartam sigillo nostro aureo praemunitam". "Et ad maioris roboris firmitatem hoc privilegium communitum nostro sigillo aureo roboramus." Cit. en BIRCH, W. de Gray: Catalogue of seals in the Departament of manuscripts in the Bristish Museum, vol. VI, London, 1920, pp. 509 y 531. [Catalogue of seals]

134 "Et porque este mío priuillegio deste mío donadio e destas mías franquezas sea más firme e más estable, e uala pora siempre, mandél sellar con mío seello de oro". "Et porque este mío priuillegio deste mío donadio e destas mías franquezas sea firme e estable, e uala pora siempre, mandél sellar con el mío seello de oro". Vid. A.M.S. Carpeta 1, ns 5 y 6.

${ }^{135}$ Cit. en M. GONZÁLEZ JIMÉNEZ, "El Puerto de Santa María en tiempos de Alfonso X (1264-1284)", Gades, 9 (1982), doc. no 1.

${ }^{136}$ Vid. W. de Gray BIRCH, Catalogue of seals.
} 


\section{ANTONIO J. LÓPEZ GUTIÉRREZ \\ LA GÉNESIS DOCUMENTAL EN LA CANCILLERÍA REAL DE ALFONSO X}

en el de plomo es "pora siempre iamás"137, y en el de cera la concesión queda ajustada a un período de tiempo concreto ${ }^{138}$. Por otra parte, se suelen utilizar también para documentos que contienen un mandato en cuyo caso el predominio corresponde al sello de cera, siendo muy escasos los ejemplos con sello de plomo ${ }^{139}$.

El sello de cera placado sobre papel, cuya utilización comienza a advertirse durante el reinado de Alfonso $\mathrm{X}^{140}$, se usa para una parte de aquellos documentos que contienen un mandato ${ }^{141}$.

Una vez que el documento había sido validado con el sello regio, los selladores posiblemente escribirían algunas notas de su puño y letra con relación al sello empleado para reflejar el ius sigillum, que recibían en concepto del sellado de documentos ${ }^{142}$. Los registros quedaban bajo la custodia de los selladores y con ellos el documento debidamente registrado y validado.

Los selladores, aparte de su labor de sellado, llevaban a cabo otras misiones recognitio signatoris y contropatio signatoris, que tienen su raíz en la naturaleza del hecho que llevan a cabo: el sellado de los documentos.

\subsubsection{Recognitio signatoris}

Infiere en dos aspectos: uno alusivo a la forma de presentarse el documento en la cancillería; el otro, a la perfección que en su factura debía tener el documento, según las normas y los usos cancillerescos.

En el primer caso, cartas cerradas, los selladores debían cuidarse mucho de no proporcionarle algún tajo o disminución al documento. Es decir, dadas las características externas de presentación del documento, la tarea de sellado tenían que realizarla con mucha más precisión que en otro tipo de cartas, como por ejemplos las abiertas. Se trata, pues, de una recognitio que va destinada a supervisar uno de los caracteres externos del documento: la escritura. Caso de que el sellador le proporcionara algún corte al documento, en zona que podría ser declara-

\footnotetext{
${ }^{137}$ Vid. A.H.N. Sección Osuna, Carpeta 6, $\mathrm{n}^{\circ}$ 6. Los ejemplos podrían multiplicarse.

${ }^{138}$ Vid. A.C.S. Caja 114, n ${ }^{\circ} 19$. Los ejemplos podrían multiplicarse.

${ }^{139}$ La utilización de la carta plomada intitulativa comienza a atisbarse durante el reinado de Alfonso X. Los ejemplos que de ella tenemos son bastantes escasos si la comparamos con la carta plomada notificativa, por ejemplo, pero a fin de cuentas van a ser unos pocos ejemplares. Vid. A.M.S. Carpeta $168, \mathrm{n}^{\mathrm{o}} 1$.

${ }^{140}$ Sobre el inicio de los sellos de placa en la cancillería regia castellana puede consultarse la obra de F. ARRIBAS ARRANZ, Sellos de placa de las cancillerías regias castellanas, Valladolid, 1941.

${ }^{141}$ Vid. Archivo Municipal de Carrizo, $\mathrm{n}^{\circ} 327$.

${ }^{142}$ A este respecto, Vid. el apartado referente a la taxatio de los documentos.
} 
da como sospechosa y consiguientemente, como documento falso, el sellador mandaba "emendar" el documento:

E deuen guardar en las cartas cerradas, que si la letra o alguna parte menguare en ellas, que las fagan emendar, porque non vayan menguadas ${ }^{143}$.

De ahí que conservando la misma terminología con la que las fuentes la describen, hemos optado por denominarla como: emendatio escriptoris.

En el segundo caso, documentos que se mostraban contra la manera usual de hacerlo en la corte, los selladores no debían sellarlo:

E deuen otrosí guardar, que si la carta alguna las aduxeren, que sea contra la manera que vsan en la corte del rey, que la non sellen ${ }^{144}$.

A menos que mostrasen el documento a aquella persona que había ejercido la iussio documental, para asegurarse de su otorgamiento y consiguientemente de su redacción ${ }^{145}$. Serían, pues, los documentos que en numerosas ocasiones se encuentra el investigador y que denomina "atípicos" por no ajustarse en su la totalidad a la normativa establecida en cancillería para esos documentos.

\subsubsection{Emendatio scriptoris}

Corre a cargo de los escribanos que redactaban los documentos. Este momento se produce cuando el escribano, autor material del documento, se dispone a “emendar" los posibles daños que haya podido ocasionar el sellador al documento mientras procedía a su sellado. Resulta enormemente significativa esta labor por parte del escribano, porque si no efectuase las correcciones oportunas al documento, éste puede ser declarado como falso, con el consiguiente perjuicio para su poseedor.

\subsubsection{Contropatio signatoris}

La labor de la contropatio se dirige a los documentos que contenían un acto confirmatorio, y a los que el sellador debía realizar esta tarea antes de proceder a

${ }^{143}$ Cfr. P.3-20-4.

${ }^{144}$ Ibidem.

${ }^{145}$ E deuen otrosi guardar, que si carta alguna les aduxeren, que sea contra la manera que vsan en la corte del rey, que la non sellen, a menos de la mostrar a aquel que la mandó fazer. Cfr. P.3-20-4; E.4-13-3. 
su sellado. La contropatio no iba dirigida únicamente al nuevo documento, sino también al presentado para confirmar con la finalidad de asegurarse que:

No están roçados, nin sopuntados, nin aya en ellos ninguna de las cosas porque los pueden desechar ${ }^{146}$.

Resulta evidente que la contropatio - que con toda seguridad fue realizada en un primer momento por el escribano, autor material del documento- cobra ahora mayor importancia desde el preciso instante en que el sellador se dispone a validarlo con el sello de la persona que lo otorga y confirma: el rey.

Así pues, tenemos ya el documento debidamente registrado y validado, y los registros de cancillería en poder de los selladores. En ellos está "copiado" el documento en sí, amén del ius sigillum ${ }^{147}$.

\subsubsection{Taxatio}

Es la fase de la conscriptio cancilleresca en la que el destinatario de la acción jurídica abona en concepto de tasas una cantidad pecuniaria con la finalidad de poder sacer el documento del registro y poder hacerse con él.

Cuestión de gran interés es la planteada por esta tasa, acerca de conocer si el canon a pagar por el documento era además del ius scripturae et ius sigilli; o bien englobando el ius scripturae et ius sigilli. A tenor de los datos que nos suministran las fuentes nos decidimos por la segunda posibilidad, dado que:

La razón, porque lo deuen tomar (se refiere a la tasa) es por el sellar, e por dar gualardón a los escriuanos, por el trabajo que lleuan ${ }^{148}$.

Este es el sentido, naturalmente, que al término taxatio otorga el Comité Internacional de Diplomática: est l'opération par laquelle était "jugé", d'apres le tarif et selon des modalités variant avec les chancelleries, la taxe à payer pour le droit de sceau et autres taxex (registre, colltion, éventuellement eluminaire, etc) ${ }^{149}$. Y que en nuestro caso sólo se refiere - al menos ninguna otra mención hemos encontrado - al ius scripturae et ius sigilli, como anteriormente apuntamos.

\footnotetext{
146 Ibidem.

147 Vid. P.3-20-4.

${ }^{148}$ Cfr. P.3-20-6.

${ }^{149}$ Cfr. Folia Caesaraugustana, I, p. 161, no 333.
} 
El "sobrante" de la taxatio iba destinado para "pro comunal"150 y también, para el pago a los distintos funcionarios de la misma, incluidos los que ostentaban el cargo de forma honorífica que por cierto, obtenían de la tenencia del cargo sabrosos beneficios ${ }^{151}$. A la cantidad a pagar nos referiremos a continuación.

El pago de tasas en la cancillería alfonsí se realizaba en función de dos factores: el contenido jurídico del documento y el destinatario del mismo. Basta observar en los cuadros adjuntos los derechos a satisfacer por cada uno de los documentos confeccionados.

A un negocio jurídico concreto -quitamiento de pecho o portazgo- le correspondían diferentes pagos de taxas si el beneficiario fuese: una villa: 100 maravedís; un hombre rico: 50 maravedís; o un pobre: 10 maravedís. Resulta evidente, que un mismo hecho jurídico devengaba distintos aranceles según su destinatario $^{152}$.

Al hilo de la anterior afirmación nos surge una nueva pregunta: ¿si a esta diferenciación en el pago de tasas podría corresponder distinta emisión en cuanto a tipología documental se refiere? Sin negar lo que de cierto pueda tener nuestra hipótesis, no podemos negar la aseveración que en las fuentes se realizaba sobre el tema:

E si diere el rey heredamiento a rico ome, que vala de renta cien maravedís, de por el privillejo, o por la carta treinta maravedís ${ }^{153}$.

Que en suma, no hace sino relegar esta posible emisión en distintos tipos diplomáticos — privilegio o carta — al contenido jurídico del documento. Por lo que nuestra hipótesis pasa a ser más una inquietud del diplomatista actual que una preocupación del beneficiario "in tempore", que se encontraba más preocupado del fondo — contenido jurídico — que de la forma — tipología documental—, porque en resumen, era el objeto deseado: beneficiarse de esos efectos jurídicos.

\footnotetext{
${ }^{150} \mathrm{Al}$ menos esa es la idea que impera en las fuentes al mencionar que la finalidad de la cancillería: E porque la chancellería del rey es fecha por pro de todos comunalmente. Cfr. E.4-12-54.

${ }^{151}$ Fernando IV, le reconoce a D. Gonzalo, arzobispo de Toledo, los derechos económicos de la cancillería de Castilla, según era costumbre de los arzobispos toledanos asignándole, por ello, una renta de 40.000 maravedís anuales sobre los derechos de la cancillería. Edit. J. M. NIETO SORIA, Las relaciones monarquía-episcopado castellano como sistema de poder (1252-1313), vol. II, Madrid, 1983, doc. $n^{\circ}$ 604, pp. 255-256.

${ }^{152}$ Vid. P.3-20-7. Vid. J. I. RUIZ DE LA PEÑA, "Poblamiento y Cartas Pueblas de Alfonso X y Sancho IV en Galicia”, en Homenaje a José María Lacarra de Miguel en su jubilación del profesorado, vol. 3, Zaragoza, 1977, p. 35, nota 18.

${ }^{153}$ Cfr. P.3-20-7.
} 
A esta conclusión tendríamos que añadir los exiguos derechos que cobraban tanto los escribanos como los selladores por realizar sus respectivas funciones, con relación a la tasa que el destinatario abonaba en cancillería.

Por otra parte, a personas de la misma categoría social podía corresponderles distinto pago de tasas en función del alcance jurídico del mismo. En concreto, nos referimos al nombramiento de canciller y de notario mayor. Las personas que deseaban obtener el documento de su nombramiento tenían que pagar distintas tasas a la cancillería: canciller: 500 maravedís; notario mayor: 300 maravedís ${ }^{154}$, hecho este que nos pone en evidencia la primacía de un cargo sobre otro.

Si a esto le añadimos que en las Partidas se recoge en qué forma de emisión debe hacerse el documento de nombramiento de oficiales: carta abierta en pergamino de cuero ${ }^{155}$, esta afirmación refuta en parte las posibles distintas formas de emisión de un documento, según lo expuesto, por el pago de tasas.

Desgraciadamente no brillan por su abundancia los datos referentes a la taxatio en los documentos originales, de ahí la dificultad de comprobar su aplicación real. De hecho estas noticias no aluden directamente a la cuantía a pagar por la expedición de algún documento en concreto, pero sí contiene datos acerca del pago de tasas en la cancillería. Así un documento por el que Alfonso X manda a Juan Ferrán, su sobrino y merino mayor de Galicia, que escudriñe la verdad acerca del pleito que mantiene doña Mayor Alfonso, con don Arias Gómez se contiene:

Et de la otra parte entregad a esta donna Mayor Alffonsso de los bienes de Arias Gómez treinta e siete marauedís de la moneda nueua por costas de las uegadas de los escritos del tiempo que duró el pleito en la mi corte e que costó esta carta en la mi chancellería ${ }^{156}$.

Que la normativa de la expedición de título de oficiales del rey a través de una carta abierta en pergamino de cuero no se cumplió es algo evidente. Al menos así lo prueba un documento fechado en Sevilla el 27 de junio de 1260 por el cual nombra a Juan García, su mayordomo, adelantado mayor de la mar, y la expedición del mismo se efectúa por medio de un privilegio rodado ${ }^{157}$.

\footnotetext{
${ }^{154}$ El Espéculo, en cambio, señala la cantidad de 200 maravedís. Vid. E.4-12-55.

${ }^{155}$ Ca las vnas deuen ser fechas en pargamino de cuero, así quando el rey da alguna merindad, o alcaldía, o alguaciladgo, o judgado, o juradería... Cfr. P.3-18-5.

${ }^{156}$ Vid. A.H.N. Clero, Carpeta 1245, $\mathrm{n}^{\mathrm{o}} 20$.

${ }^{157}$ El documento conservado en el Archivo Municipal de Villamayor está publicado por L. SERRANO, El mayordomo de doña Berenguela, Madrid, 1934, pp. 197-198.
} 
Al pago de tasas de cancillería nos referimos en los siguientes cuadros adjuntos. Si bien antes hemos de hacer una observación a ellos, en el sentido de que la nomenclatura tradicional se ha impuesto de tal manera que resulta prácticamente imposible sustituirla, aún con los riesgos que en su caso conlleva. Es el caso de los términos, privilegio y carta (carta de privilegio). No se nos oculta que el privilegio no es una categoría diplomática sino una nomenclatura que responde a un concepto jurídico concreto; ni que el término carta es un genérico que tampoco responde en el sentido estricto a una categoría diplomática. Con estas salvedades, los cuadros que siguen en el apartado de categorías diplomáticas hemos mantenido la terminología tradicional.

De estas tasas de cancillería, como anteriormente señalamos, tenemos que sustraer el ius scripturae y el ius sigilli. Comparando la cuantía a pagar a uno y otro por la labor desempeñada, deducimos la importancia que tenían los selladores sobre los escribanos, porque de hecho sus tasas eran el doble que la de los escribanos. Ello viene a poner de manifiesto la importancia del sello del documento, cuya validez jurídica ha sido examinada al referirnos a él.

Pasamos a enumerar las tasas que nos hacen referencia al ius scripturae y al ius sigilli:

\begin{tabular}{|l|l|l|}
\hline CATEGORÍAS DIPLOMÁTICAS & IUS SCRIPTURAE & IUS SIGILLI \\
\hline Privilegio Rodado & $\begin{array}{l}1 \text { maravedís } \\
\text { (incluido el signo) }\end{array}$ & 2 maravedís \\
\hline Carta Plomada & 0,5 maravedí & 1 maravedí \\
\hline Carta Abierta, pergamino de cuero & 0,5 maravedí & 0,5 maravedí \\
\hline
\end{tabular}

Cumplidos los momentos procesales que hemos venido refiriendo, y registrado el documento, serán los registros de cancillería los instrumentos de los que ésta se valdrá para ulteriores expediciones de documentos en ellos contenidos. Quizá no sería necesario insistir en esto, y si lo dejamos anotado es porque todas las fuentes insisten en esta función de los libros-registros.

E otrosí deben guardar, que non sellen carta ninguna a menos de ser registrada, nin la den otrosí del registro, sin mandado del rey ${ }^{158}$.

${ }^{158}$ Cfr. P.3-20-4. 


\subsubsection{Expeditio}

Entendemos por tal, la entrega en mano del documento al destinatario de la acción jurídica. ¿Quiénes eran las personas que se encontraban facultadas para llevar a cabo esta función? Se trata de aquellas mismas personas que se encontraban facultadas para ejercer la iussio documental, es decir: el rey ${ }^{159}$, el canciller ${ }^{160}$, el notario ${ }^{161}$ y los alcaldes ${ }^{162}$.

La expeditio adopta dos sistemas: sistemas directo e indirecto.

En el primer caso - sistema directo - el documento es entregado por el autor de la iussio documental al destinatario de la acción jurídica. Si nos atenemos a la letra del ordenamiento alfonsí (resulta evidente que no siempre la realidad se correspondió a este ordenamiento) la expedición de los privilegios de nueva elaboración, las renovaciones, las confirmaciones, corrían a cargo del rey, si bien, la iussio fue dada por el notario, éste debe con posterioridad aducirlo ante el rey para su aprobación ${ }^{163}$. La entrega de documentos por el rey se justifica en las fuentes por el peso de la tradición y por la gratitud que para el rey debía surgir el hecho de la entrega del documento de concesión gratiosa:

E esto touieron los sabios antiguos porque non pudiessen y ser fecho yerro ninguno; e otrosí porque los que rescibiessen los preuillejos e las gracias del rey lo agradeciesen a aquel que es poderoso de los dar e de cuyas manos los recibe ${ }^{164}$.

Sin duda, que en este texto, cumplidamente literario hay resonancias del viejo ceremonial de la encomendación.

Las carta de gracia y merced han de ser entregadas también por el rey o por otras personas — canciller, notarios o alcaldes - que actúan en su representación y mandato $^{165}$.

Los alcaldes entregan las cartas foreras ${ }^{166}$; y los mandamientos judiciales y los oficiales a quienes el rey encomendase dar ${ }^{167}$.

${ }^{159}$ Vid. P.2-9-8; P. 3-18-3; P.3-20-3.

${ }^{160}$ Vid. P.2-9-8; P.3-20-3; P.4-18-13.

${ }^{161}$ Vid. P.2-9-8; P.3-18-3; P.3-20-3.

162 Vid. P.3-20-3.

${ }^{163}$ Nin aun maguer que los mande fazer chanceller o notario, nos los deve dar ninguno destos, más después que fueren escriptos e plomados, deven los adozir ante el rey. Cfr. P.3-18-26. E.4-6-3.

${ }^{164}$ Cfr. P.3-18-26.

${ }^{165}$ Carta ninguna, que sea de gracia o de merced que el rey faga a alguno, que otro non la pueda dar si non el rey u otro por su mandado, de aquellos que lo deuen fazer; así como chanceller, o notario, o alguno de los otros que ha de juzgar en la corte, así como adelantados, o alcaldes. Cfr. P.3-18-26. 
En el segundo caso - sistema indirecto- el documento es entregado al destinatario de la acción jurídica por un enviado del autor de la iussio. Es en definitiva, un servicio de índole postal, servicio que a veces lo ejercía el portero del rey.

Como colofón a nuestra expositio, adjuntamos un croquis en el que el lector puede apreciar el iter que ha seguido el documento para su confección en la cancillería real castellana en tiempos de Alfonso X.

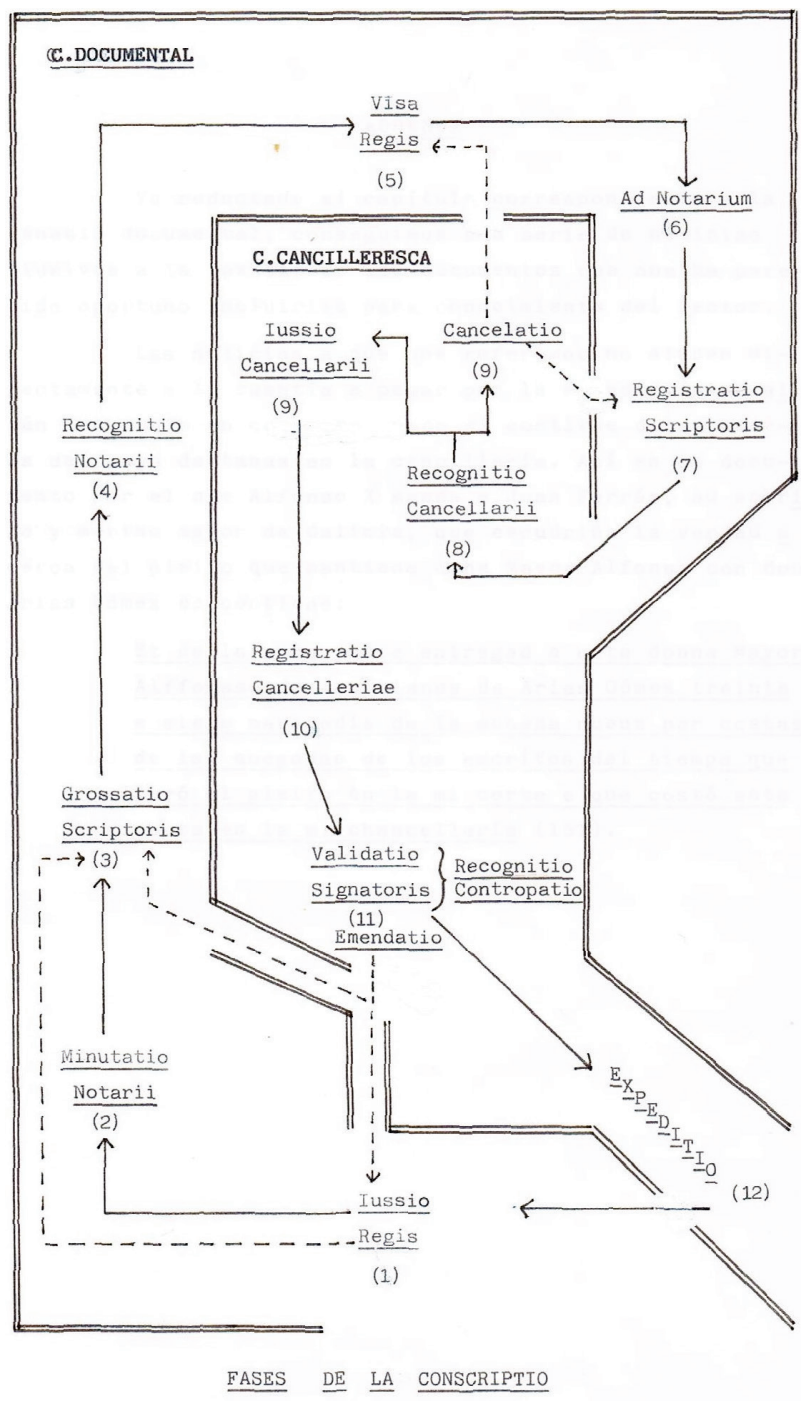

${ }^{166}$ Las cartas foreras, e los juicios que judgaren, dezimos otrosí, que las pueden dar los adelantados, o los alcaldes de casa del rey. Cfr. P.3-18-26.

${ }^{167}$ E las otras cartas que son en razón de las cosas que el rey manda fazer, o recabdar, también de fecho en justicia, como de rentas, o de cosechas o de cuentas; e otrosí de mandaderías, o en las otras cosas que tengan en fecho del rey, o de su corte, o de su casa, o de las otras cosas que son suyas conoscidamente por el reyno; nos las deue mandar dar si non el rey, o aquellos officiales a que las él mandare dar señaladamente. Cfr. P.3-18-26. 
TABLAS DE PAGOS DE DERECHOS POR LA TAXATIO

\begin{tabular}{|c|c|c|c|c|}
\hline $\begin{array}{l}\text { NEGOCIO } \\
\text { JURÍDICO }\end{array}$ & DESTINATARIO & $\begin{array}{l}\text { PRECISIONES } \\
\text { JURÍDICAS } \\
\end{array}$ & $\begin{array}{l}\text { CATEGORÍAS } \\
\text { DIPLOMÁTICAS }\end{array}$ & TASAS \\
\hline $\begin{array}{l}\text { Concesión de } \\
\text { Fuero }\end{array}$ & Villa & & Privilegio & 100 maravedís \\
\hline $\begin{array}{l}\text { Concesión de } \\
\text { Heredamiento }\end{array}$ & Puebla Nueva & $\begin{array}{l}\text { con término } \\
\text { poblado }\end{array}$ & Privilegio & 50 maravedís \\
\hline $\begin{array}{l}\text { Concesión de } \\
\text { Heredamiento }\end{array}$ & Puebla Nueva & $\begin{array}{l}\text { sin término } \\
\text { poblado }\end{array}$ & & 20 maravedís \\
\hline $\begin{array}{l}\text { Concesión de } \\
\text { Heredamiento }\end{array}$ & $\begin{array}{l}\text { Ciudad o villa } \\
\text { Grande }\end{array}$ & $\begin{array}{l}\text { con término } \\
\text { poblado }\end{array}$ & Privilegio & 100 maravedís \\
\hline $\begin{array}{l}\text { Concesión de } \\
\text { Heredamiento }\end{array}$ & $\begin{array}{l}\text { Ciudad o villa } \\
\text { Grande }\end{array}$ & $\begin{array}{c}\text { con tierras } \\
\text { yermas }\end{array}$ & & 50 maravedís \\
\hline $\begin{array}{l}\text { Concesión de } \\
\text { Heredamiento }\end{array}$ & Villa Menor & $\begin{array}{l}\text { con término } \\
\text { poblado }\end{array}$ & & 50 maravedís \\
\hline $\begin{array}{l}\text { Concesión de } \\
\text { Heredamiento }\end{array}$ & Villa Menor & por poblar & & 20 maravedís \\
\hline $\begin{array}{l}\text { Concesión de } \\
\text { Heredamiento }\end{array}$ & Villa Menor & si es tan grande & Privilegio & 40 maravedís \\
\hline $\begin{array}{l}\text { Concesión de } \\
\text { Heredamiento }\end{array}$ & Villa Menor & más a su pro & & $\begin{array}{c}\text { A determinar } \\
\text { por el rey }\end{array}$ \\
\hline $\begin{array}{c}\text { Quitamiento de } \\
\text { Pecho o de } \\
\text { Portazgo }\end{array}$ & Villa & & & $\begin{array}{c}100 \\
\text { maravedís*168 }\end{array}$ \\
\hline $\begin{array}{c}\text { Quitamiento de } \\
\text { Pecho o de } \\
\text { Portazgo }\end{array}$ & Hombre Rico & & & 50 maravedís \\
\hline $\begin{array}{l}\text { Quitamiento de } \\
\text { Pecho o de } \\
\text { Portazgo }\end{array}$ & Pobre & & & 10 maravedís \\
\hline $\begin{array}{l}\text { Concesión de } \\
\text { Feria }\end{array}$ & Ciudad o Villa & & Privilegio & 100 maravedís \\
\hline $\begin{array}{l}\text { Concesión de } \\
\text { Mercado }\end{array}$ & Lugar & & & 30 maravedís \\
\hline $\begin{array}{c}\text { Donación de } \\
\text { Heredamientos }\end{array}$ & Rico Ome & $\begin{array}{l}\text { de renta } 100 \\
\text { maravedís }\end{array}$ & Privilegio o Carta & 30 maravedís \\
\hline $\begin{array}{c}\text { Donación de } \\
\text { Heredamientos }\end{array}$ & Rico Ome & $\begin{array}{l}\text { más o menos } \\
\text { maravedís }\end{array}$ & & A esta razón \\
\hline
\end{tabular}

${ }^{168}$ Se entiende 100 maravedís por pecho y/o 100 por portazgo. 
ANTONIO J. LÓPEZ GUTIÉRREZ

LA GÉNESIS DOCUMENTAL EN LA CANCILLERÍA REAL DE ALFONSO X

\begin{tabular}{|c|c|c|c|c|}
\hline $\begin{array}{l}\text { Donación de } \\
\text { Heredamientos }\end{array}$ & $\begin{array}{c}\text { Arzobispo, } \\
\text { Obispo, Hombre } \\
\text { de Orden de los } \\
\text { Mayorales } \\
\text { Maestro, Prior, } \\
\text { Comendados, } \\
\text { Abad } \\
\end{array}$ & para la Orden & Privilegio o Carta & 100 maravedís \\
\hline $\begin{array}{l}\text { Donación de } \\
\text { Heredamientos }\end{array}$ & $\begin{array}{c}\text { Arzobispo, } \\
\text { Obispo, Hombre } \\
\text { de Orden de los } \\
\text { Mayorales } \\
\text { Maestro, Prior, } \\
\text { Comendados, } \\
\text { Abad }\end{array}$ & $\begin{array}{c}\text { Para sí mismos, } \\
\text { valiendo de } \\
\text { renta } 100 \\
\text { maravedís }\end{array}$ & Privilegio o Carta & 30 maravedís \\
\hline $\begin{array}{l}\text { Donación de } \\
\text { Heredamientos }\end{array}$ & $\begin{array}{c}\text { Caballero de } \\
\text { Mesnada, Clérigo } \\
\text { de su Casa, } \\
\text { Alcalde de Corte u } \\
\text { hombre de su } \\
\text { criazón }\end{array}$ & $\begin{array}{l}\text { Si vale de renta } \\
100 \text { maravedís }\end{array}$ & Privilegio o Carta & 20 maravedís \\
\hline $\begin{array}{l}\text { Donación de } \\
\text { Heredamientos }\end{array}$ & $\begin{array}{c}\text { Caballero de } \\
\text { Mesnada, Clérigo } \\
\text { de su Casa, } \\
\text { Alcalde de Corte u } \\
\text { hombre de su } \\
\text { criazón }\end{array}$ & $\begin{array}{l}\text { más o menos } \\
\text { maravedís }\end{array}$ & & A esta razón \\
\hline Confirmaciones & Orden o Concejo & $\begin{array}{c}\text { términos, } \\
\text { donadíos, } \\
\text { heredamientos } \\
\end{array}$ & Privilegio & 20 maravedís \\
\hline Confirmaciones & Rico Ome & $\begin{array}{c}\text { Términos y } \\
\text { heredamientos }\end{array}$ & Privilegio & 20 maravedís \\
\hline Confirmaciones & & Resto & Privilegio & 10 maravedís \\
\hline Nombramiento & Rico Ome & $\begin{array}{c}\text { Ponga } \\
\text { maravedís en } \\
\text { tierra } \\
\end{array}$ & Carta & $\begin{array}{l}3 \% \text { valor en } \\
\text { maravedís }\end{array}$ \\
\hline Nombramiento & & Alférez & & 300 maravedís* \\
\hline Nombramiento & & Mayordomo & & 300 maravedís* \\
\hline Nombramiento & & Canciller & & $\begin{array}{c}500 \\
\text { maravedís*169 }\end{array}$ \\
\hline Nombramiento & & Notario Mayor & & 300 maravedís \\
\hline Nombramiento & & Merino mayor & & 200 maravedís \\
\hline Nombramiento & & $\begin{array}{c}\text { Adelantado } \\
\text { Mayor }\end{array}$ & & 200 maravedís \\
\hline Nombramiento & & $\begin{array}{l}\text { Almirante } \\
\text { Mayor }\end{array}$ & & 200 maravedís \\
\hline
\end{tabular}

${ }^{169}$ El Espéculo señala para estos casos 200 maravedís. 


\begin{tabular}{|c|c|c|c|}
\hline Nombramiento & $\begin{array}{l}\text { Alguacil de su } \\
\text { Casa }\end{array}$ & & 30 maravedís \\
\hline Nombramiento & $\begin{array}{l}\text { Alcalde de su } \\
\text { corte }\end{array}$ & & 30 maravedís \\
\hline Nombramiento & $\begin{array}{l}\text { Mandaderos a } \\
\text { tierra de moros }\end{array}$ & & 200 maravedís \\
\hline Nombramiento & Copero Mayor & & 40 maravedís \\
\hline Nombramiento & Portero & & 40 maravedís \\
\hline Nombramiento & Repostero & & 40 maravedís \\
\hline Nombramiento & Despensero & & 40 maravedís \\
\hline Nombramiento & Cocinero Mayor & & 20 maravedís \\
\hline Nombramiento & Catiquero & & 20 maravedís \\
\hline Nombramiento & Caballerizo & & 20 maravedís \\
\hline Nombramiento & Posadero & & 20 maravedís \\
\hline Nombramiento & Cevadero & & 20 maravedís \\
\hline Nombramiento & $\begin{array}{c}\text { Sustituto } \\
\text { Mayordomo } \\
\text { Mayor }\end{array}$ & & 20 maravedís \\
\hline Nombramiento & $\begin{array}{c}\text { Alcalde Villa o } \\
\text { Merindad }\end{array}$ & & 10 maravedís \\
\hline Nombramiento & $\begin{array}{c}\text { Juez Villa o } \\
\text { Merindad } \\
\end{array}$ & & 10 maravedís \\
\hline Nombramiento & $\begin{array}{c}\text { Marino Villa o } \\
\text { Merindad }\end{array}$ & & 10 maravedís \\
\hline Nombramiento & $\begin{array}{l}\text { Adelantado } \\
\text { Villa }\end{array}$ & & 10 maravedís \\
\hline Nombramiento & $\begin{array}{c}\text { Escribano de } \\
\text { Concejo }\end{array}$ & & 5 maravedís* \\
\hline Nombramiento & Entregador & & 5 maravedís*170 \\
\hline Nombramiento & $\mathrm{Rab}$ & & 200 maravedís \\
\hline Nombramiento & $\begin{array}{c}\text { Almoxarifes } \\
\text { Villas }\end{array}$ & & 100 maravedís \\
\hline Nombramiento & $\begin{array}{c}\text { Almoxarifes } \\
\text { Villas Menores }\end{array}$ & & 50 maravedís \\
\hline Nombramiento & $\begin{array}{l}\text { Viejo Mayor } \\
\text { sobre Tierra } \\
\end{array}$ & & 100 maravedís \\
\hline Nombramiento & $\begin{array}{c}\text { Viejo Mayor en } \\
\text { el Aljama }\end{array}$ & & 20 maravedís \\
\hline $\begin{array}{c}\text { Sacar Cosas } \\
\text { vedadas del } \\
\text { Reino }\end{array}$ & $\begin{array}{l}\text { Oro, plata, argén } \\
\text { vivo, grana, } \\
\text { seda, cueros, } \\
\text { paños, } \\
\text { corambre, cera y } \\
\text { cordobanes }\end{array}$ & Carta & $\begin{array}{l}1 \% \text { valor en } \\
\text { maravedí }\end{array}$ \\
\hline
\end{tabular}

${ }^{170}$ El Espéculo señala como tasa para estos casos 100 maravedís. 
ANTONIO J. LÓPEZ GUTIÉRREZ

LA GÉNESIS DOCUMENTAL EN LA CANCILLERÍA REAL DE ALFONSO X

\begin{tabular}{|c|c|c|c|c|}
\hline $\begin{array}{l}\text { Sacar Cosas } \\
\text { vedadas del } \\
\text { Reino }\end{array}$ & & Caballos & Carta & 1 maravedí \\
\hline $\begin{array}{l}\text { Sacar Cosas } \\
\text { vedadas del } \\
\text { Reino }\end{array}$ & & Rocines & Carta & 1 maravedí \\
\hline $\begin{array}{l}\text { Sacar Cosas } \\
\text { vedadas del } \\
\text { Reino }\end{array}$ & & Mulo y Mula & Carta & 1 maravedí \\
\hline Avenencias & $\begin{array}{c}\text { Ricos Omes, } \\
\text { Obispos, Concejos } \\
\text { y Órdenes }\end{array}$ & & Carta & $\begin{array}{c}20 \\
\text { maravedís*171 }\end{array}$ \\
\hline Avenencias & $\begin{array}{c}\text { Un hombre con } \\
\text { otro }\end{array}$ & & Carta & $\begin{array}{c}20 \\
\text { maravedís } * 172\end{array}$ \\
\hline Avenencias & $\begin{array}{c}\text { Concejo y otro en } \\
\text { juicio }\end{array}$ & & Carta & $\begin{array}{c}10 \\
\text { maravedís*173 }\end{array}$ \\
\hline $\begin{array}{l}\text { Arrendamientos } \\
\text { rey }\end{array}$ & & Puerto o salinas & Carta & $\begin{array}{l}0,5 \% \text { valor en } \\
\text { maravedís }{ }^{\wedge 174}\end{array}$ \\
\hline Pleitos & & $\begin{array}{l}\text { Sin entrega de } \\
\text { ambas partes }\end{array}$ & Carta & 5 sueldos \\
\hline Pleitos & & $\begin{array}{l}\text { Con entrega de } \\
\text { una parte la } \\
\text { parte vencedora }\end{array}$ & Carta & $\begin{array}{l}1 \% \text { valor en } \\
\text { maravedís*175 }\end{array}$ \\
\hline Perdón & Rico Ome & $\begin{array}{c}\text { Justicia en el } \\
\text { cuerpo }\end{array}$ & Carta & 10 maravedís \\
\hline Perdón & Pobre & $\begin{array}{c}\text { Justicia en el } \\
\text { cuerpo }\end{array}$ & Carta & 5 maravedís \\
\hline Perdón & & De haber & Carta & $\begin{array}{c}1 \% \text { valor en } \\
\text { maravedís }\end{array}$ \\
\hline Pagos & & $\begin{array}{c}\text { Hasta } 1.000 \\
\text { maravedís }\end{array}$ & Carta & 1 maravedí \\
\hline Pagos & & $\begin{array}{c}\text { Más de } 1.000 \\
\text { maravedís }\end{array}$ & Carta & 1 maravedí \\
\hline Deuda & & $\begin{array}{l}\text { Colocándole los } \\
\text { maravedís en } \\
\text { lugar señalado }\end{array}$ & Carta & $\begin{array}{c}0,5 \% \text { valor en } \\
\text { maravedís }\end{array}$ \\
\hline Guiaje & & $\begin{array}{c}\text { Con todas sus } \\
\text { cosas }\end{array}$ & Carta & 5 maravedí* 176 \\
\hline $\begin{array}{l}\text { Recomendación } \\
\text { a los judíos }\end{array}$ & $\begin{array}{l}\text { Villa mayor con } \\
\text { sus términos }\end{array}$ & $\begin{array}{c}\text { Para que le } \\
\text { atiendan las } \\
\text { deudas }\end{array}$ & Carta & 12 maravedís \\
\hline
\end{tabular}

${ }^{171}$ Se entiende cada uno.

172 Se entiende cada uno.

${ }^{173}$ La parte que venciere.

${ }^{174}$ Se entiende la primera vez.

${ }^{175}$ La parte que venciere.

${ }^{176}$ El Espéculo señala como tasa para este caso 100 maravedís. 
ANTONIO J. LÓPEZ GUTIÉRREZ

LA GÉNESIS DOCUMENTAL EN LA CANCILLERÍA REAL DE ALFONSO X

\begin{tabular}{|c|c|c|c|c|}
\hline $\begin{array}{c}\text { Recomendación } \\
\text { a los judíos }\end{array}$ & Villa mediana & $\begin{array}{c}\text { Para que le } \\
\text { atiendan las } \\
\text { deudas }\end{array}$ & Carta & 6 maravedís \\
\hline $\begin{array}{c}\text { Recomendación } \\
\text { a los judíos }\end{array}$ & Villa menor & $\begin{array}{c}\text { Para que le } \\
\text { atiendan las } \\
\text { deudas }\end{array}$ & Carta & 3 maravedís \\
\hline Pagos & $\begin{array}{c}\text { A mano de } \\
\text { portero }\end{array}$ & Carta & $\begin{array}{c}1 \% \text { valor en } \\
\text { maravedí }\end{array}$ \\
\hline $\begin{array}{c}\text { Manda dar } \\
\text { algunos } \\
\text { maravedís }\end{array}$ & $\begin{array}{c}\text { de } 10 \text { maravedís } \\
\text { hasta 100 }\end{array}$ & Carta & 5 sueldos \\
\hline $\begin{array}{c}\text { Manda dar } \\
\text { algunos } \\
\text { maravedís }\end{array}$ & $\begin{array}{c}\text { más de 100 } \\
\text { maravedís }\end{array}$ & Carta & $\begin{array}{c}1 \% \text { valor en } \\
\text { maravedís }\end{array}$ \\
\hline $\begin{array}{c}\text { Manda dar } \\
\text { algunos } \\
\text { maravedís }\end{array}$ & $\begin{array}{c}\text { Menos de 10 } \\
\text { maravedís }\end{array}$ & Carta & Nada \\
\hline $\begin{array}{c}\text { Simple justicia } \\
\text { Simple justicia }\end{array}$ & $\begin{array}{c}\text { Faga derecho } \\
\text { sobre querella }\end{array}$ & Carta & 5 sueldos \\
\hline $\begin{array}{c}\text { Manada por } \\
\text { atiendan por } \\
\text { maravedí que } \\
\text { deba }\end{array}$ & $\begin{array}{c}\text { Déndo de } 100 \\
\text { algún concejo }\end{array}$ & Carta & 1 maravedí \\
\hline $\begin{array}{c}\text { Renovaciones } \\
\text { adelante }\end{array}$ & Carta & 1 maravedí \\
\hline
\end{tabular}

Tablas de pagos de derechos por la taxatio. 